\title{
Synapse Loss in Cortex of Agrin-Deficient Mice after Genetic Rescue of Perinatal Death
}

\author{
Iwona Ksiazek, ${ }^{1}$ Constanze Burkhardt, ${ }^{1}$ Shuo Lin, ${ }^{1}$ Riad Seddik, ${ }^{2}$ Marcin Maj, ${ }^{1}$ Gabriela Bezakova, ${ }^{1}$ Mathias Jucker, ${ }^{3}$ \\ Silvia Arber, ${ }^{1,4}$ Pico Caroni, ${ }^{4}$ Joshua R. Sanes, ${ }^{5}$ Bernhard Bettler, ${ }^{2}$ and Markus A. Ruegg ${ }^{1}$ \\ ${ }^{1}$ Biozentrum and ${ }^{2}$ Institute of Physiology, Department of Clinical-Biological Sciences, University of Basel, CH-4056 Basel, Switzerland, ${ }^{3}$ Department of \\ Cellular Neurology, Hertie-Institute of Clinical Brain Research, D-72076 Tübingen, Germany, ${ }^{4}$ Friedrich Miescher Institute, CH-4058 Basel, Switzerland, \\ and ${ }^{5}$ Department of Molecular and Cellular Biology, Harvard University, Cambridge, Massachusetts 01238
}

\begin{abstract}
Agrin-deficient mice die at birth because of aberrant development of the neuromuscular junctions. Here, we examined the role of agrin at brain synapses. We show that agrin is associated with excitatory but not inhibitory synapses in the cerebral cortex. Most importantly, we examined the brains of agrin-deficient mice whose perinatal death was prevented by the selective expression of agrin in motor neurons. We find that the number of presynaptic and postsynaptic specializations is strongly reduced in the cortex of 5- to 7-week-old mice. Consistent with a reduction in the number of synapses, the frequency of miniature postsynaptic currents was greatly decreased. In accordance with the synaptic localization of agrin to excitatory synapses, changes in the frequency were only detected for excitatory but not inhibitory synapses. Moreover, we find that the muscle-specific receptor tyrosine kinase MuSK, which is known to be an essential component of agrin-induced signaling at the neuromuscular junction, is also localized to a subset of excitatory synapses. Finally, some components of the mitogen-activated protein (MAP) kinase pathway, which has been shown to be activated by agrin in cultured neurons, are deregulated in agrin-deficient mice. In summary, our results provide strong evidence that agrin plays an important role in the formation and/or the maintenance of excitatory synapses in the brain, and we provide evidence that this function involves MAP kinase signaling.
\end{abstract}

Key words: neuromuscular synapse; gene expression; excitatory synapse; MuSK; spines; MAP kinase

\section{Introduction}

The molecular mechanisms involved in the formation of the postsynaptic apparatus are well understood at the neuromuscular junction (NMJ), where spinal motor neurons synapse on muscle fibers. The most important players involved in NMJ development are the motor neuron-released molecule agrin and the muscle-specific proteins MuSK, acetylcholine receptor (AChR), and rapsyn (McMahan, 1990; Sanes and Lichtman, 2001; Bezakova and Ruegg, 2003). The receptor tyrosine kinase MuSK is the signaling receptor activated by agrin, and rapsyn is a cytosolic adaptor molecule that links MuSK signaling to AChR clustering. Although agrin is not required to form AChR aggregates before innervation, motor neuron-derived agrin is required to induce and maintain the AChR aggregates that are closely associated with the nerve terminal and that persist after the onset of electrical activity (Sanes and Lichtman, 2001; Bezakova and Ruegg, 2003). Consistent with this concept, agrin-deficient mice die at

Received Sept. 1, 2006; revised May 25, 2007; accepted May 26, 2007.

This work was supported by the Swiss National Science Foundation and the Kanton of Basel-Stadt. We thank L. Bondolfi, I. Knuesel, S. Naegele-Tollardo, A. Probst, and U. Sauder for technical support and H. R. Brenner for the ErbB-deficient mice. We thank J. M. Fritschy, J.P. Hornung, and A. Probst for invaluable discussions, M. Galic for the critical reading of this manuscript, and M. Stebler for assistance with the microarray data. We also acknowledge the help of $U$. Deutsch with the breeding of the mice.

Correspondence should be addressed to Dr. Markus A. Ruegg, Biozentrum, University of Basel, Klingelbergstrasse 70, CH-4056 Basel, Switzerland. E-mail: markus-a.ruegg@unibas.ch.

DOI:10.1523/JNEUROSCI.1609-07.2007

Copyright $\odot 2007$ Society for Neuroscience $\quad$ 0270-6474/07/277183-13\$15.00/0 birth because of respiratory failure. Similarly, inactivation of MuSK or rapsyn causes respiratory failure.

Formation of synapses in the CNS shares many features with the NMJ. For example, neurotransmitter release is not required to form both presynaptic and postsynaptic specializations (Verhage et al., 2000), suggesting that adhesive interactions are responsible for synapse assembly. Indeed, several adhesion molecules have now been implicated in synapse formation in the brain (for review, see Akins and Biederer, 2006). Although agrin is also expressed in the brain, its role is controversial. For example, synaptic deficits in agrin-deficient mice have only been observed in the PNS (Gingras et al., 2002) but not in embryonic brain. Although cortical neurons from heterozygous and homozygous agrin knock-out mice are more resistant to damage triggered by excitatory neurotransmitters (Hilgenberg et al., 2002), synapses still form in such neurons ( $\mathrm{Li}$ et al., 1999; Serpinskaya et al., 1999). These experiments thus indicate that agrin signaling is not required for the formation of neuron-to-neuron synapses.

In contrast, there is evidence that agrin may have a function at neuron-to-neuron synapses. Most importantly, acute suppression of agrin expression by antisense oligonucleotides impairs synapse formation and dendritic development in cultured hippocampal neurons (Ferreira, 1999; Bose et al., 2000). Moreover, agrin added to cultured neurons activates signaling pathways that are known to be involved in synapse function, such as the transcription factor cAMP response element-binding protein 
(CREB) (Ji et al., 1998), the immediate-early gene c-fos (Hilgenberg et al., 1999), or the mitogen-activated protein (MAP) kinase pathway (Karasewski and Ferreira, 2003; Hilgenberg and Smith, 2004). Finally, alternative splicing of the agrin transcript generates a protein isoform that is inserted into plasma membranes as a type II transmembrane protein (Burgess et al., 2000; Neumann et al., 2001). This form is highly expressed in neurons. Thus, unlike the situation at the NMJ, agrin expressed in CNS neurons does not require a structured basement membrane.

To clarify the role of agrin in the formation of synapses in the CNS, we now examined the brain of agrin-deficient mice in which perinatal death was prevented by the transgenic expression of agrin in motor neurons. We find that there is a loss of synapses in the cortex of these rescued mice and that agrin loss selectively affects excitatory but not inhibitory synapses. These results are thus the first to provide strong evidence for a role of agrin in the formation and/or the maintenance of excitatory synapses in the brain.

\section{Materials and Methods}

Generation of Tg/agrn ${ }^{-1-}$ mice. The cDNA encoding the 9-kb-long promoter region of mouse $\mathrm{Hb} 9$ was cloned into pBluescript (pBS). To release the final $\mathrm{Hb} 9$-agrin construct (see Fig. 1a) from the pBS backbone, we first inserted an additional PacI restriction site at the $5^{\prime}$ end of the pBS-Hb9 construct by adaptor ligation. The cDNA encoding full-length chick agrin was inserted downstream of this construct by AscI/XbaI double digestion. The final construct was then released by PacI digestion and injected into oocytes. Transgenic mice were identified by PCR and Southern blot analysis using primers and probes from the $3^{\prime}$ untranslated region of chick agrin mRNA. From six transgenic founders, three permanent lines were established that expressed chick agrin. Each of the transgenic lines was mated with heterozygous agrin-deficient mice (Lin et al., 2001), giving birth to transgenic heterozygous agrin-deficient mice ( $\mathrm{Tg} /$ $\left.\mathrm{agrn}^{+/-}\right)$. These mice were then mated with heterozygous agrin-deficient mice. The line that gave rise to surviving $\mathrm{Tg} / \mathrm{agrn}^{-1-}$ mice first was used for the analysis described here. For most experiments, 6- to 7-week-old mice of both genders were used. Control animals were usually littermates of the same age. Whenever possible, these animals were wild type or transgenic for $\mathrm{Hb} 9$-agrin. In a few cases, heterozygous agrin knock-out mice were used.

Antibodies. Anti-agrin antibodies included rabbit antisera raised against the C-terminal half of chick (Gesemann et al., 1995) or mouse (Eusebio et al., 2003) agrin and the mouse monoclonal antibody 5B1 (Reist et al., 1987). Antibodies to the $\alpha 1$ or the $\alpha 2$ subunits of $\mathrm{GABA}_{\mathrm{A}}$ receptors were raised in guinea pigs and were a kind gift from J.-M. Fritschy (University of Zurich, Zurich, Switzerland). Anti-MuSK antibodies were raised against the extracellular domain of mouse MuSK that had been expressed in 293 EBNA cells (Invitrogen, San Diego, CA) as a His-tagged fusion protein and were purified from culture medium using a Ni-column. This antiserum recognizes MuSK in Western blots and immunohistochemistry (see supplemental Fig. 2, available at www.jneurosci.org as supplemental material). All of the other antibodies used were from the following commercial sources: rabbit antibodies against synaptophysin (Dako, High Wycombe, UK), neurofilament (Sigma, St. Louis, MO), S-100 (Dako), glial fibrillary acidic protein (Dako), and SynGAP (Affinity Bioreagents); and mouse monoclonal antibodies against CaMKII $\alpha$ (calcium/calmodulin-dependent protein kinase II $\alpha$; 6G9; Affinity Bioreagents, Golden, CO), gephyrin (Mab7a; Connex, Martinsried, Germany), phospho-c-jun N-terminal kinase (JNK; Cell Signaling Technology, Danvers, MA), mitogen-activated protein kinase kinase 7 (MKK7; 611246; BD Biosciences, Franklin Lakes, NJ), NR1 (54.1; PharMingen, San Diego, CA), synaptophysin (MAB5258; Chemicon, Temecula, CA), and postsynaptic density protein-95 (PSD-95; K28/86; Upstate Biotechnology, Lake Placid, NY). Detection was done using the appropriate, affinity-purified secondary antibodies coupled to either Cy3 (Jackson ImmunoResearch, West Grove, PA) or Alexa 488 (Invitrogen).

Stereological analysis. The analysis was performed as described previ- ously (Calhoun et al., 1998). Briefly, mice were perfused with $0.1 \mathrm{M}$ PBS, $\mathrm{pH} 7.4$, followed by $4 \%$ paraformaldehyde (PFA) in PBS, and the brains were dehydrated in ethanol (70, 83, and $96 \%$ for $1 \mathrm{~h}$ each). After $15 \mathrm{~min}$ in $100 \%$ ethanol, the brains were kept in a 1:1 cedarwood oil/ethanol mixture and then in cedarwood oil at $60^{\circ} \mathrm{C}$, each for $1 \mathrm{~h}$. Excess oil was removed by immersion in a 1:1 cedarwood oil/methyl salicylate mixture overnight and in $100 \%$ methyl salicylate for $1 \mathrm{~h}$. Brains were embedded into paraffin using standard procedures, and $25-\mu \mathrm{m}$-thick coronal sections were cut using a rotatory microtome. Total numbers of neocortical neurons and synaptophysin-positive puncta were counted on cresyl violet- and synaptophysin-stained sections, respectively. A systematic random series of every 20th section throughout the entire cortex was selected, yielding 10 15 sections per animal. To stain for synaptophysin, sections were quenched with $0.3 \% \mathrm{H}_{2} \mathrm{O}_{2}$ in methanol, followed by blocking in $5 \%$ goat serum. Sections were incubated with primary antibodies overnight at $4^{\circ} \mathrm{C}$ and then with biotinylated secondary antibodies, $\mathrm{ABC}$ solution (Vector Laboratories, Burlingame, CA), and 0.08\% diaminobenzidine $/ 0.03 \% \mathrm{H}_{2} \mathrm{O}_{2}$ in PBS. Quantification was performed by estimating the volume of the cortex according to the Cavalieri method (grid point area, $500 \mu \mathrm{m}^{2}$ ) and multiplying it by the numerical density, which was determined by counting objects within three-dimensional optical dissectors ( $16 \mu \mathrm{m}^{3}$ for boutons, $4200 \mu \mathrm{m}^{3}$ for neurons), systematically spaced throughout the neocortex. On average, $75 \pm 23$ and $103 \pm 21$ dissectors per mouse were counted for synapses and neurons, respectively. Only cells with a typical neuronal morphology (clear nucleolus or discrete, darkly stained synaptophysin-positive boutons) were counted $(100 \times ; 1.3$ numerical aperture objective; on-screen magnification, $2759 \times)$. Analysis was performed with stereological software (SPA, Alexandria, VA).

Golgi-Cox impregnation. Freshly isolated brains were impregnated in a 15:5:4 mixture of potassium dichromate, mercuric chloride, and potassium chromate solutions ( $5 \%$ each) for 3 weeks in the dark. After dehydration in ethanol (70\% for $12 \mathrm{~h}, 96$ and $100 \%$ for $24 \mathrm{~h}$ each), brains were impregnated with celloidin solution $(2,4$, and $8 \%$ for 24,48 , and $72 \mathrm{~h}$, respectively) and cut into 80 - to $100-\mu \mathrm{m}$-thick coronal sections, which were then processed for Golgi-Cox staining. Staining was visualized by incubation in $25 \% \mathrm{NH}_{4} \mathrm{OH}$ for $30 \mathrm{~min}$, followed by $0.5 \%$ phenylenediamine for $4 \mathrm{~min}, 1 \%$ Dektol (Eastman Kodak, Rochester, NY) for $2 \mathrm{~min}$, $5 \%$ fixative solution (G305) for $5 \mathrm{~min}$, and acetate buffer at $\mathrm{pH} 4.1$ for 5 min. After dehydration in ethanol, sections were mounted, and well impregnated pyramidal neurons were reconstructed using Neurolucida software.

Locomotion. Exploratory locomotion was examined in an open-field test. Mice were placed into a new cage, and the time they spent moving during the first $10 \mathrm{~min}$ was measured manually.

Immunohistochemistry. Double immunofluorescence for excitatory synaptic markers was performed by the antigen-unmasking method with pepsin pretreatment (Watanabe et al., 1998). Other stainings on brain tissue were performed as described previously (Fritschy et al., 1998). Whole-mount staining of muscle was performed as described previously (Bezakova and Lomo, 2001). Cultured neurons were washed with PBS, fixed with $4 \%$ PFA in PBS, permeabilized with $0.1 \%$ Triton X-100, and blocked with $10 \%$ fetal calf serum in PBS for $1 \mathrm{~h}$ at room temperature. Cells were incubated with primary antibodies overnight at $4^{\circ} \mathrm{C}$, washed, and further incubated with secondary antibodies for $2 \mathrm{~h}$ at room temperature. All images were analyzed using fluorescence or confocal laserscanning microscopy (Leica, Nussloch, Germany) and the appropriate imaging software.

Immunoelectron microscopy. Mice were perfused with PBS, followed by $4 \%$ PFA in PBS. Cortices were postfixed in the same fixative overnight, followed by $0.5 \% \mathrm{OsO}_{4}$ for $30 \mathrm{~min}$. After dehydration in ethanol (50 and $70 \%$ for 10 min each), tissue was infiltrated with a 2:1 mixture of ethanol and LR White, followed by pure LR White ( $1 \mathrm{~h}$ each), and polymerized at $70^{\circ} \mathrm{C}$ for $24 \mathrm{~h}$. Sixty-nanometer-thick microtome sections were first incubated with agrin antiserum (1:500) and then with $10 \mathrm{~nm}$ gold-coupled secondary antibodies (1:20). For quantification, all gold particles within $100 \mathrm{~nm}$ of the middle of the synaptic cleft of randomly selected synapses were counted.

Electrophysiological measurements. Recordings were made from visu- 
ally identified pyramidal neurons located in layer II/III of the motor cortex. Slices were prepared from 4- to 5-week-old mice. Parasagittal slices (300 $\mu \mathrm{m}$ thick) were cut with a Leica VT1000S in ice-cold artificial CSF (aCSF) containing (in mM) $119 \mathrm{NaCl}, 1 \mathrm{NaH}_{2} \mathrm{PO}_{4}, 26.2 \mathrm{NaHCO}_{3}$, $2.5 \mathrm{KCl}, 2.5 \mathrm{CaCl}_{2}, 1.3 \mathrm{MgCl}_{2}$, and 11 glucose, $\mathrm{pH} 7.3$, equilibrated with $95 \% \mathrm{O}_{2} / 5 \% \mathrm{CO}_{2}$. Slices were then kept in oxygenated aCSF at room temperature for at least $1 \mathrm{~h}$ before starting recordings at $30-32^{\circ} \mathrm{C}$. Pyramidal neurons were visualized using an infrared-sensitive camera (Hitachi, Tokyo, Japan) and oblique illumination optics (BX51WI; Olympus, Tokyo, Japan). Synaptic activity was recorded from cortical pyramidal cells by a whole-cell voltage-clamp technique using an Axopatch 200B amplifier (Molecular Devices, Union City, CA). Patch electrodes (3-5 $\mathrm{M} \Omega$ ) were filled with a solution containing (in mM) $135 \mathrm{CsMeSO}_{4}, 8$ $\mathrm{NaCl}, 10$ HEPES, 0.5 EGTA, $4 \mathrm{Mg}$-ATP, and 0.3 Na-GTP, pH 7.25 (adjusted with $\mathrm{CsOH}$ ). Series resistance was not compensated. Currents were digitized at $20 \mathrm{kHz}$ using a Digidata 1322A interface (Molecular Devices) driven by pClamp 9.2 software (Molecular Devices). Slices were continuously superfused $(1.5-2 \mathrm{ml} / \mathrm{min})$ with oxygenated aCSF supplemented with $0.5 \mu \mathrm{M}$ TTX (Latoxan, Valence, France) to record miniature EPSCs (mEPSCs) and miniature IPSCs (mIPSCs). mEPSCs and mIPSCs were recorded at a holding potential of -70 and $0 \mathrm{mV}$, respectively. All mEPSCs were measured in the presence of $100 \mu \mathrm{M}$ picrotoxin (a selective $\mathrm{GABA}_{\mathrm{A}}$ receptor antagonist; Sigma), and mIPSCs were measured in the presence of $2 \mathrm{~mm}$ kynurenic acid (a selective glutamate receptor antagonist; Sigma). The detection and analysis of miniature currents were achieved by the Minianalysis software (version 6.0.3; Synaptosoft, Decatur, GA). For statistical analysis, the one-way ANOVA test was used. All values are given as mean \pm SEM.

Preparation of brain lysates, brain membranes, synaptic plasma membranes, and immunoblotting. For total brain lysates, tissue was homogenized in radioimmunoprecipitation assay buffer $(150 \mathrm{~mm} \mathrm{NaCl}$, $50 \mathrm{~mm}$ Tris- $\mathrm{HCl}, \mathrm{pH} 8.0,1 \% \mathrm{NP}-40,0.5 \%$ sodium deoxycholate, and $0.1 \% \mathrm{SDS} ; 3 \mathrm{ml} / \mathrm{g}$ tissue) with a protease inhibitor mixture on ice. Samples were centrifuged at $10,000 \times g$ for $10 \mathrm{~min}$ at $4^{\circ} \mathrm{C}$, and supernatants were collected. For brain membranes, cortices were homogenized with a glass-Teflon homogenizer in 10 vol of ice-cold 10 mu Tris-HCl, pH 7.4, containing $320 \mathrm{~mm}$ sucrose and protease inhibitors. The homogenate was centrifuged at $700 \times g$ for $10 \mathrm{~min}$ at $4^{\circ} \mathrm{C}$, and the pellet was resuspended and spun again at $700 \times g$. Supernatants were combined and centrifuged at $37,000 \times g$ at $4^{\circ} \mathrm{C}$ for $40 \mathrm{~min}$. This high-speed pellet (P2) was resuspended in $10 \mathrm{~mm}$ Tris- $\mathrm{HCl}, \mathrm{pH}$ 7.4, containing protease inhibitors. Protein concentration was determined using the BCA protein assay (Pierce, Rockford, IL). Further purification of synaptic plasma membranes (SPMs) was performed as described previously (Jones and Matus, 1974). Separation of proteins by SDS-PAGE was done using $7.5 \%$ or $4-8 \%$ polyacrylamide gels.

Microarray analysis. Total RNA was prepared by Trizol extraction (Sigma) from triplicate samples of cortices of 4-week-old $\mathrm{Tg} / \mathrm{agrn}^{-\prime-}$ and control littermates. For microarray analysis, RNA was reverse transcribed using Superscript II reverse transcriptase (Invitrogen) and oligo-dT as primers. Resulting cDNA was used as a template for the production of biotin-labeled cRNA using a RNA transcript labeling kit (Affymetrix, Santa Clara, CA). Finally, the labeled cRNA was purified using RNeasy spin columns (Qiagen, Chatsworth, CA), fragmented, and hybridized to Affymetrix Mouse Genome 430 2.0 Arrays, as recommended by the manufacturer. Raw expression signals for each transcript were computed using the algorithm implemented in MAS 5.0 (Affymetrix). The robust multichip average method, implemented as a part of the BioConductor package affy, was used for data normalization, background correction, and summarization. The hybridization signal intensity was analyzed with Gene Spring 6.1 software (Silicon Genetics, Fremont, CA). In this study, the fold-change analysis method was used to select genes differentially expressed in each genotype. The increase or decrease in mRNA level was considered reliable if the difference in hybridization signal intensity between a control and $\mathrm{Tg} / \mathrm{agrn}^{-1-}$ samples yielded at least a twofold change $(<0.5$ or $>2.0)$ as described previously (Soriano et al., 2000; Matzilevich et al., 2002). For each genotype, three gene chips were used. Only genes showing a less than twofold or more than twofold change in at least $83 \%$ (five of six) of comparisons were selected as differentially expressed for further analysis. The fold-change value for each gene was calculated based on the mean and SD of comparisons that had the highest, more reliable, individual fold-change values. These selected genes were then subjected to extensive, gene-by-gene literature research and divided into functional classes based on their putative functions reported in the literature.

RNA extraction and reverse transcription-PCR for MuSK. Total RNA was extracted from $50 \mathrm{mg}$ of cortex tissue using $1 \mathrm{ml}$ of TRI reagent and the Fast Prep FP120 apparatus (Savant, Hicksville, NY) for homogenization. Residual proteins were extracted by chloroform. RNA was precipitated with isopropanol, washed with ice-cold $75 \%$ ethanol, and recentrifuged for $5 \mathrm{~min}$ at $7500 \times g\left(4^{\circ} \mathrm{C}\right)$. The RNA pellet was air dried and dissolved in $80 \mu \mathrm{l}$ of DEPC-treated water. Single-stranded cDNA was prepared from $5 \mu \mathrm{g}$ of total RNA using SuperScript II Reverse Transcriptase (Invitrogen) according to the supplier's instruction. PCR was performed for 33 cycles using the forward primer $5^{\prime}$ CTGGATCAAGGGGGACAAT- 3 ' and the reverse primer $5^{\prime}$-CTCTGGTACCGGAAGGAGA-3'. PCR products were analyzed on a $2 \%$ agarose gel.

\section{Results}

Restoration of nerve-muscle synapse in agrin-deficient mice Neural agrin secreted from motor neurons is required for the formation of NMJs (Gautam et al., 1996; Burgess et al., 1999). Because neural agrin injected into muscle is sufficient to induce postsynaptic structures (Cohen et al., 1997; Jones et al., 1997), we hypothesized that neural agrin released from motor neurons in otherwise agrin-deficient mice might prevent the perinatal death. To test this idea, we generated transgenic $(T g)$ mice that express the cDNA encoding neural chick agrin under the control of the 9 $\mathrm{kb}$ promoter region of the motor neuron-specific homeobox transcription factor Hb9 (Arber et al., 1999; Thaler et al., 1999) (Fig. 1a). Using antibodies that recognize chick but not mouse agrin, we found that NMJs of $\mathrm{Tg}$ mice were positive for the transgene (Fig. $1 b$ ) and that the transgene did not alter the structure of the NMJs (see supplemental Fig. 1, available at www.jneurosci. org as supplemental material). In a few muscles, such as soleus or the diaphragm, chick agrin was also detected in extrasynaptic regions, and these agrin deposits often induced aggregation of AChRs at nonsynaptic sites (Fig. 1b), as does neural agrin injected into the muscle (Bezakova et al., 2001). The $\mathrm{Tg}$ mice were then bred with heterozygous agrin knock-out mice (Lin et al., 2001) to generate offspring that were homozygous for the agrin deletion and expressed the transgene (called herein $\mathrm{Tg}_{\mathrm{agrn}}{ }^{-1}$ ). $\mathrm{Tg} /$ $\mathrm{agrn}^{-1-}$ mice were born with the expected Mendelian frequency and, in contrast to agrin-deficient mice, were able to move and breathe. NMJs of 6- to 7-week-old Tg/agrn $^{-1-}$ mice looked normal in most muscles including extensor digitorum longus (EDL) or tibialis anterior (TA) (Fig. 1c). In some muscles, such as soleus and diaphragm, AChR clusters were found throughout the entire muscle, and the motor nerve terminals strongly sprouted (soleus) (Fig. 1c). These muscles also atrophied, indicative of denervation. $\mathrm{Tg}_{\mathrm{agrn}}{ }^{-1-}$ mice were also considerably smaller than their control littermates (Hausser et al., 2006), and half of the mice had died after $50 \mathrm{~d}$ (Fig. 1d). Death was often preceded by impairment of locomotory behavior (Fig. 1e) and some fibrillation (data not shown), suggesting that neuromuscular defects may contribute to lethality but central defects may also play a role. For our analysis of the brain phenotype (see below), we took 30- to 50-d-old mice that did not show signs of fibrillation or locomotory impairment. 
Agrin localizes to excitatory but not inhibitory synapses in the brain Agrin staining in the brain is most prominent in the blood vessels and in pial basement membranes (Barber and Lieth, 1997; Halfter et al., 1997). Moreover, neurons in the CNS have been shown to express mRNA encoding agrin isoforms that contain amino acid inserts at the $\mathrm{B} / \mathrm{z}$ site (O'Connor et al., 1994; Stone and Nikolics, 1995). Because we focused in this work on the role of agrin at synapses, we first examined the distribution of agrin in different regions of the adult brain that are rich in synapses using antibodies raised against mouse agrin (Eusebio et al., 2003). We examined the neuropil of the CA3 region, the dentate gyrus, and the cortex, where we found agrin-like immunoreactivity associated in puncta (Fig. 2a). In agreement with other studies, the strongest immunoreactivity was found in blood vessels (Fig. $2 a$, arrow). In Tg/agrn ${ }^{-1-}$ mice, the antiserum stained neither blood vessels nor the puncta (Fig. 2a), confirming the specificity of the anti-mouse agrin antiserum. As shown in Figure $2 b$, agrinpositive puncta (red) often overlapped with staining obtained with antibodies against the presynaptic marker synaptophysin (green). This colocalization of agrin- and synaptophysin-like immunoreactivity (Fig. $2 b$, arrowheads), together with the fact that the synaptophysinpositive puncta outnumbered those for agrin, indicates that agrin is localized to a subset of synapses. As shown in Figure $2 c$, agrin-like immunoreactivity was detected in brain homogenates (lysate) and in subcellular fractions enriched for SPMs that were isolated by differential centrifugation in a sucrose gradient, according to Jones and Matus (1974). Agrin-like immunoreactivity migrated on SDS-PAGE as a smear with an apparent molecular mass between 400 and $600 \mathrm{kDa}$ (Fig. $2 c$, arrowhead). As observed in other tissues, the anti-agrin antibodies also recognized several smaller bands (Fig. $2 c$, asterisks) that are likely the product of proteolytic degradation. In summary, our results indicate that agrin in the adult brain is localized to synapses and that the synaptically localized agrin is also a proteoglycan as it is in other tissues (Tsen et al., 1995).

To assure that the agrin-immunoreactive puncta indeed represented synapses, we also used postembedding immunoelectron microscopy. First, we confirmed that the anti-agrin antiserum was also specific in immunoelectron microscopy. To this end, we examined blood vessels, which are strongly positive for agrin (Fig. $2 a$ ), and compared the staining in the basal lamina of wild-type and $\mathrm{Tg} / \mathrm{agrn}^{-/-}$mice. Indeed, many immunogold particles were found in wild-type controls but not in Tg/agrn ${ }^{-1-}$ mice (Fig. $3 a$ ). In the cerebral cortex from wild-type controls, agrin immunostaining was associated with both presynaptic and postsynaptic membranes, and it often appeared within the synaptic cleft (Fig. $3 b$ ). We could not detect any preference of the gold particles to either the presynaptic or the postsynaptic site of the synapses, which is probably attributable to the fact that agrin is a large,
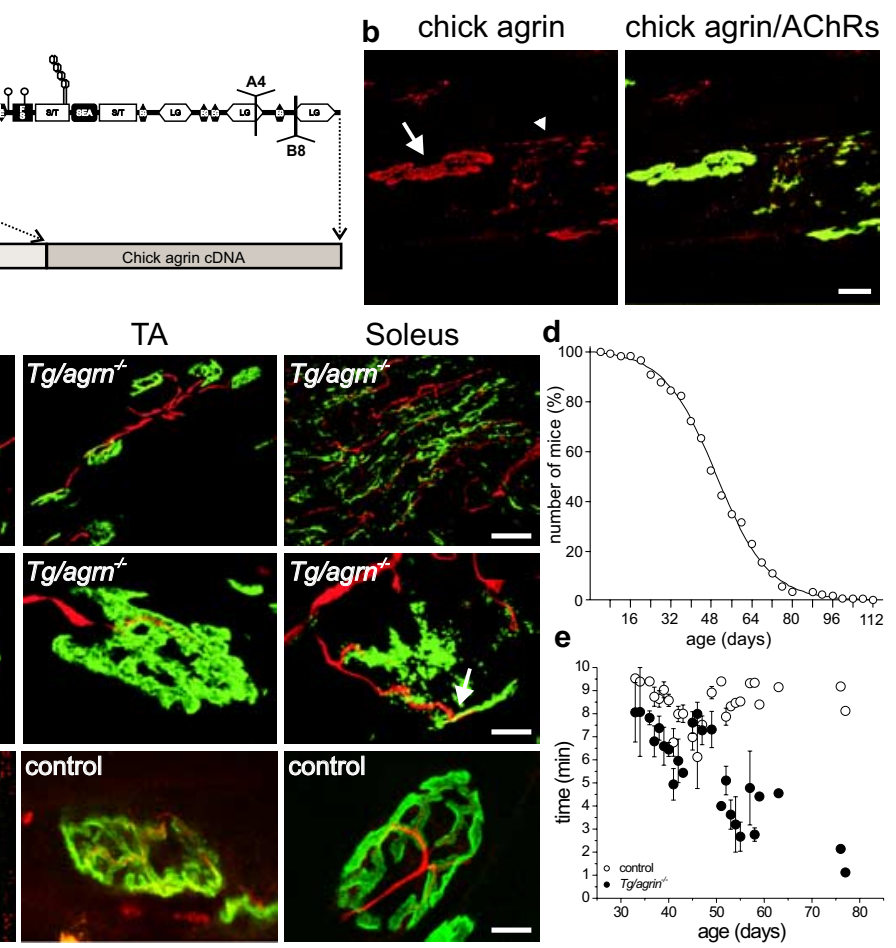

Figure 1. Characterization of mice used in this study. $\boldsymbol{a}$, Schematic representation of neural chick agrin (top) and of the DNA construct (bottom) used to generate $\mathrm{Tg} / \mathrm{agrn}^{-/-}$mice. A 9-kb-long genomic region encoding the promoter of the motor neuronpecific homeobox gene $\mathrm{Hb} 9$ was cloned upstream of the agrin cDNA. $\boldsymbol{b}$, Soleus muscle from $\mathrm{Tg}$ mice stained for chick agrin (red) ( (red) and $\alpha$-bungarotoxin to label AChRs (green). Muscle fibers are properly innervated in EDL and $40 \mu \mathrm{m}$; middle and bottom rows, $10 \mu \mathrm{m}$. d, Survival analysis of $\mathrm{Tg} / \mathrm{agrn}^{-1-}$ mice. The mean survival time of the mice was $50 \mathrm{~d}$ Note the rather large variation in survival time. e, Exploratory locomotion of $\mathrm{Tg}_{\mathrm{agrn}}{ }^{-/-}$(filled circles) and control (open circles) mice. There is no difference between the two genotypes, except at a higher age ( $>50 \mathrm{~d}$ ) at which $\mathrm{Tg} / \mathrm{agrn}{ }^{-1-}$ are close to dying.

95-nm-long particle as determined by rotary shadowing (Denzer et al., 1998). Thus, depending on the plane of the section, agrin could be at either side of the synapse. In contrast to the staining in wild-type mice, only few immunogold particles were detected in sections from $\mathrm{Tg} / \mathrm{agrn}^{-1-}$ mice (Fig. $3 b$ ). To get a quantitative measure for the synaptic localization of agrin, we counted the immunogold particles within a 100 -nm-wide area (i.e., the size of agrin) surrounding the synaptic cleft. This quantification yielded an average of 1.4 gold particles per synapse (Fig. $3 c$ ). In contrast, $T g /$ $\mathrm{agrn}^{-/-}$mice contained only $\sim 0.6$ gold particles in synaptic regions, which is not significantly different from the number of particles in nonsynaptic regions of control mice (Fig. 3c). From these results, we conclude that agrin is indeed enriched at synapses.

During these electron microscopic studies, we noticed that agrin-like immunogold particles were predominantly associated with asymmetric (excitatory) but not with symmetric (inhibitory) synapses. To validate this impression, we stained cross sections from cerebral cortex for agrin and for the $\alpha 2$ subunit of the $\mathrm{GABA}_{\mathrm{A}}$ receptors. Strong immunoreactivity for both proteins was detected around the soma and in the neuropil (Fig. $3 d$ ). However, the dot-like staining for either protein did not overlap significantly (Fig. $3 d$, merge). The same results were obtained in other regions of the brain, including hippocampus and dentate gyrus (data not shown). Similarly, agrin-like immunoreactivity did not colocalize with gephyrin (data not shown), an adaptor 
a

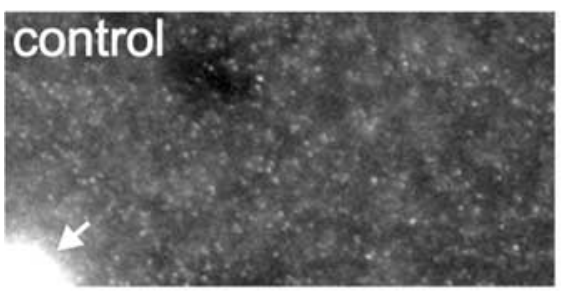

\section{ctx}
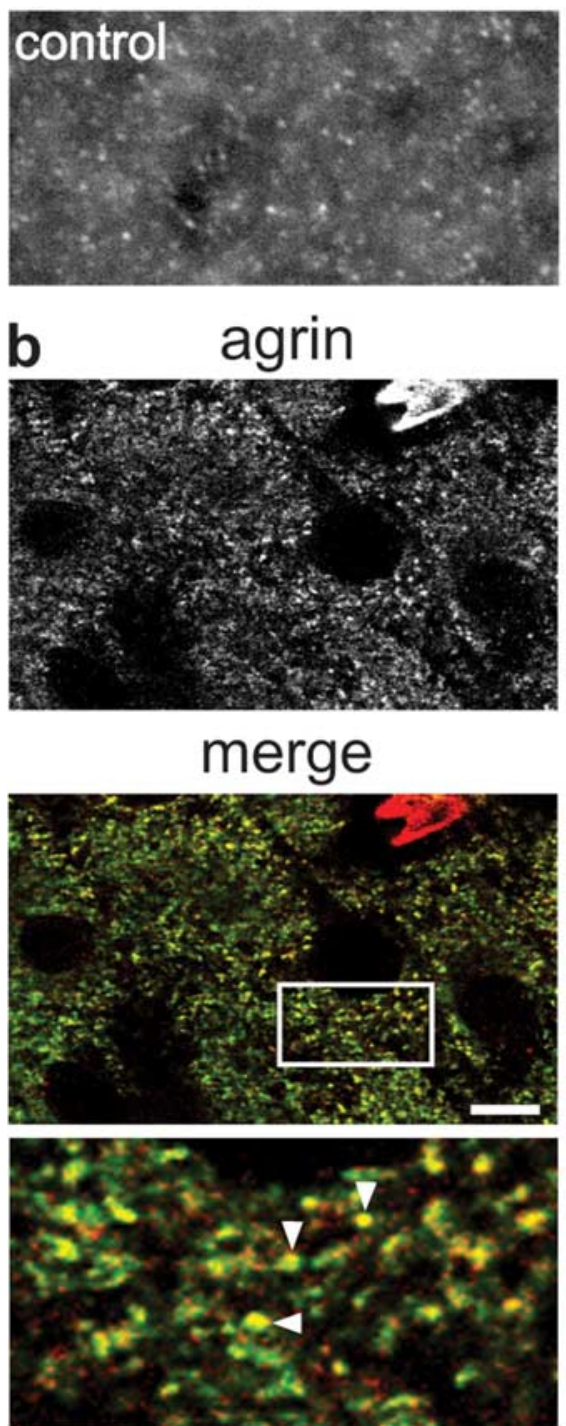

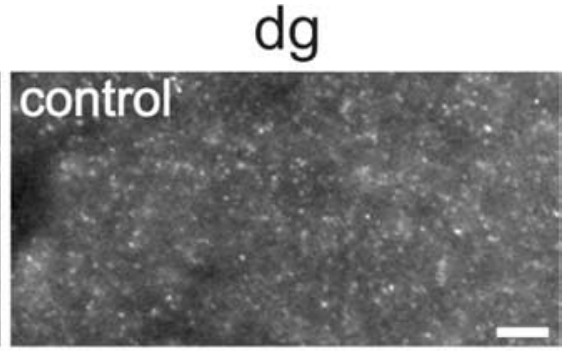

ctx

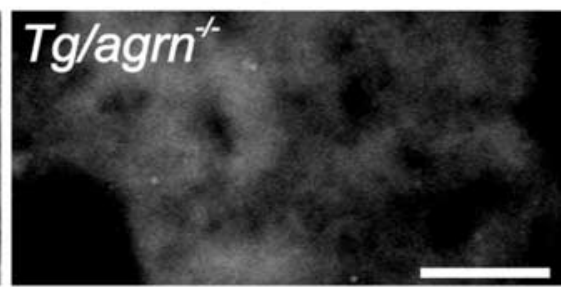

synaptophysin

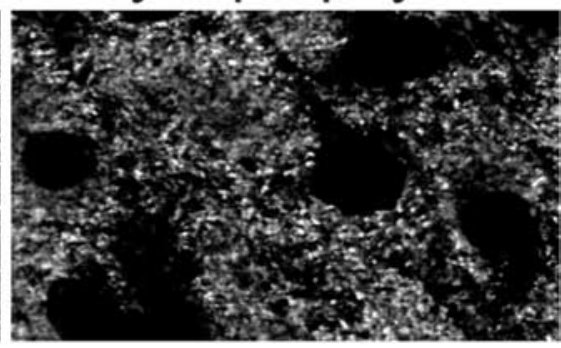

c lysate SPM

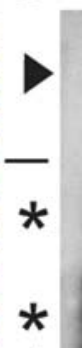

*

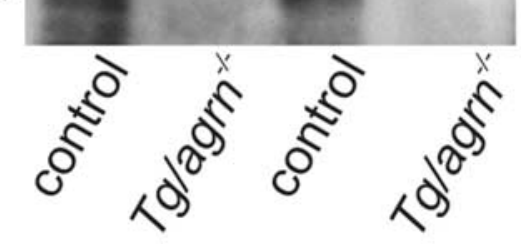

Figure 2. Agrin-like immunoreactivity in the brain. $\boldsymbol{a}$, In control animals, agrin staining is most prominent in blood vessels (arrow). Agrin-like protein also shows a dot-like pattern in the CA3 region of the hippocampus, the dentate gyrus (dg), and the cerebral cortex (ctx). No agrin-like immunoreactivity was detected in agrin-deficient mice ( $\mathrm{Tg}_{\mathrm{agrn}}{ }^{-/-}$; ctx). $\boldsymbol{b}$, Sections of cerebral cortex of control mice were stained with antibodies against agrin (red) and the presynaptic marker synaptophysin (green). The bottom picture represents a higher-power view of the framed region. A fraction of the synaptophysin-positive puncta is also positive for agrin-like immunoreactivity (see examples highlighted by arrowheads). c, Western blot analysis using antiagrin antibodies of crude brain lysates (lysate) and of preparations enriched for SPMs. Agrin-like protein in control mice appears as a smear with an apparent molecular mass of $400-600 \mathrm{kDa}$ (arrowhead) and in several smaller bands (asterisks). None of these bands were visible in samples isolated from $\mathrm{Tg}_{\mathrm{agrn}}{ }^{-1}$ mice. The line indicates marker size of $250 \mathrm{kDa}$. Scale bars, $20 \mu \mathrm{m}$.

protein required for the clustering of glycine and $\mathrm{GABA}_{\mathrm{A}}$ receptors. Moreover, $\mathrm{GABA}_{\mathrm{A}}$ receptor $\alpha 2$ subunit and gephyrin remained coclustered in $\mathrm{Tg} / \mathrm{agrn}^{-1-}$ mice (data not shown). In contrast, the staining for PSD-95, a marker for excitatory syn- apses (for review, see Kim and Sheng, 2004), showed some overlap with the puncta that were positive for agrin-like immunoreactivity (Fig. $3 e$, arrowheads). Colocalization between agrin and PSD-95 was not seen in all cases, and the PSD-95positive puncta outnumbered those positive for agrin (Fig. $3 e$, arrow). These experiments are thus strong evidence that agrin localizes to a subset of excitatory but not inhibitory synapses in the adult mouse cortex.

The number of synapses is reduced in Tg/agrn $^{-/-}$mice

Next, we examined how agrin deficiency affected the brain. As shown in Figure 4, $a$ and $b$, the overall morphology of the brain as visualized in serial cresyl violet-stained paraffin sections was unchanged. Likewise, no significant change in the overall morphology of pyramidal neurons in the hippocampus could be detected by Golgi impregnation (Fig. 4c,d). Thus, unlike other main components of the pial basement membranes, such as perlecan or some of the laminin chains (Miner et al., 1998; Costell et al., 1999; Halfter et al., 2002), agrin seems not to be essential for the development of the laminar structure of the brain and for the proper differentiation of neurons.

Next, we wanted to see whether synapse number and/or structure was affected. One complication in determining synapse number is the fact that $\mathrm{Tg} /$ agrn $^{-/-}$mice are significantly smaller than control mice. Because size differences can be caused by either changes in cell number or in cell volume, we first quantified the total number of neurons in the cortex using cresyl violet-stained sections in combination with modern, unbiased stereology (Calhoun et al., 1998). As shown in Figure 4e, neuronal cell bodies (arrowheads) were smaller and more densely packed in $\mathrm{Tg} / \mathrm{agrn}^{-/-}$ mice, which resulted in a significantly higher density of neurons in Tg/agrn ${ }^{-1-}$ mice (Fig. 4f). Because the total volume of the cortex, as determined by stereology, was smaller in $\mathrm{Tg} / \mathrm{agrn}^{-/-}$mice (Fig. $4 g$ ), the total number of neurons in the entire cortex of $\mathrm{Tg} / \mathrm{agrn}^{-1-}$ mice remained the same as in control mice (Fig. $4 h)$. By using the same method of unbiased stereology in combination with staining for the presynaptic marker protein synaptophysin, we then determined the density of synaptophysin-positive puncta in a given volume. As shown in Figure $4 i$, this parameter was the same in $\mathrm{Tg} / \mathrm{agrn}^{-1-}$ and control mice. Because the total volume of the cortex is considerably smaller in $\mathrm{Tg} / \mathrm{agrn}^{-/-}$mice than in con- 
a
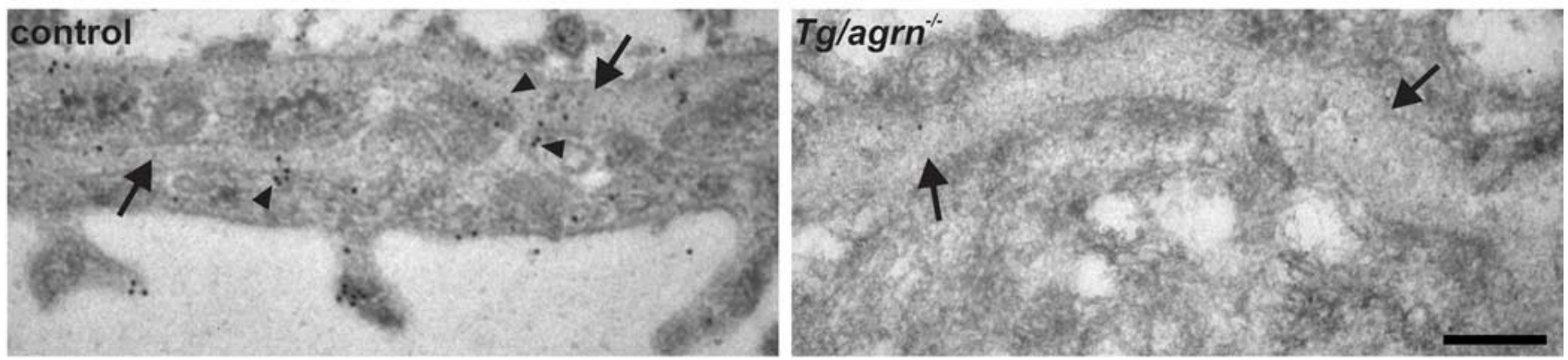

b

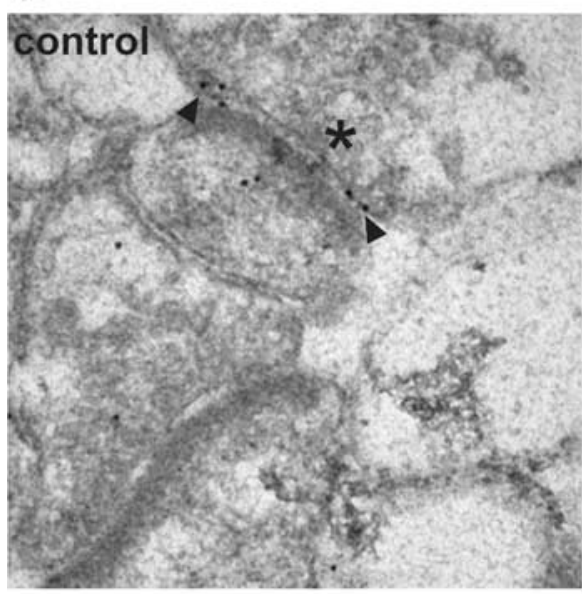

d

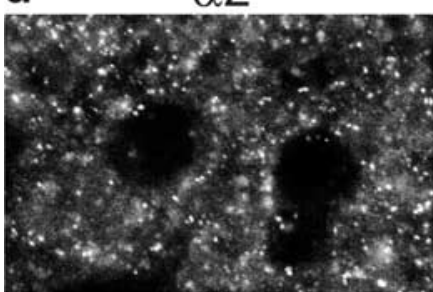

e

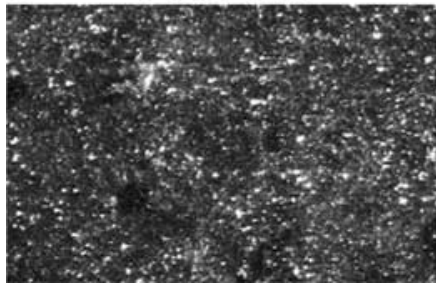

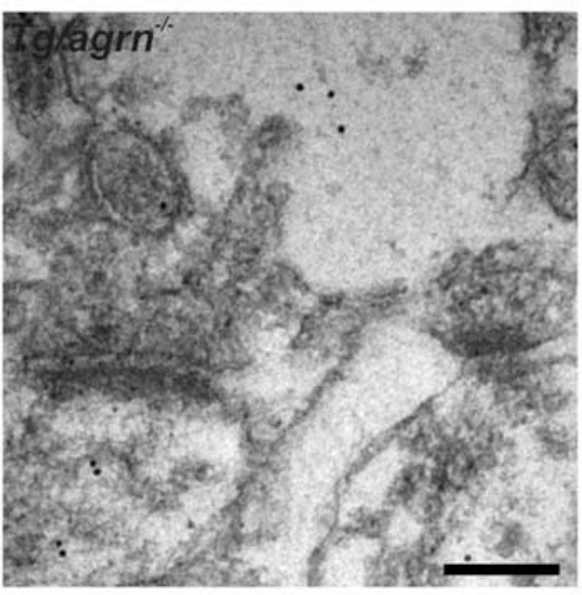

agrin

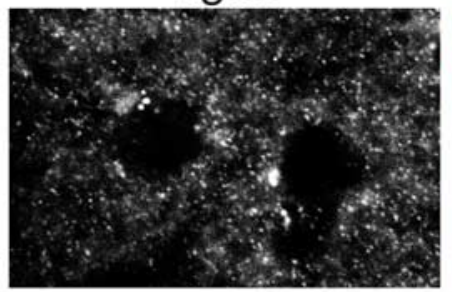

agrin

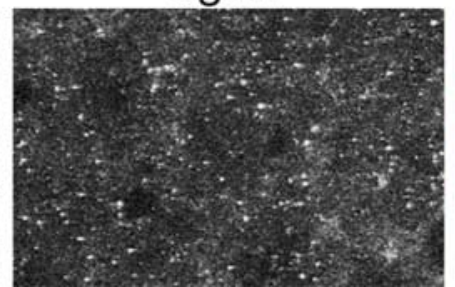

merge

merge
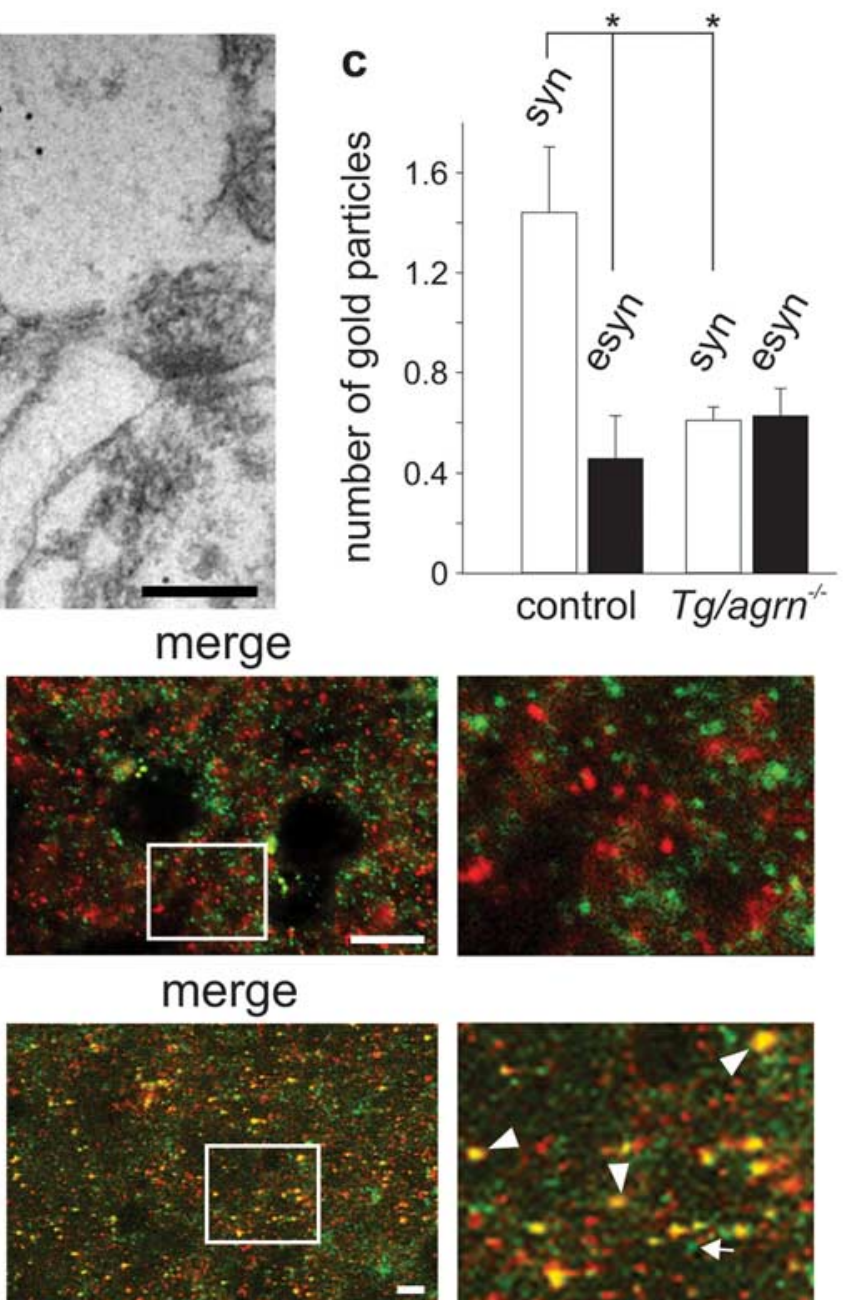

Figure 3. Agrin-like immunoreactivity in the cerebral cortex is enriched at synapses and is localized to a subset of excitatory synapses. $\boldsymbol{a}$, Basal lamina surrounding blood vessels (arrows) contained agrin-like immunoreactivity (arrowheads) in control but not in $\mathrm{Tg}_{\mathrm{agrn}}{ }^{-1-}$ mice. Note that the basal lamina of $\mathrm{Tg} / \mathrm{agrn}{ }^{-1-}$ mice was often thicker than that of control mice. $\boldsymbol{b}$, Agrin immunogold particles (arrowheads) were found near presynaptic (asterisk) and postsynaptic membranes and within the synaptic cleft. c, Quantification of the distribution of agrin immunogold particles. In control mice, the number of gold particles was significantly higher at synaptic (syn) than at extrasynaptic (esyn) regions. No synaptic enrichment was detected in $\mathrm{Tg} / \mathrm{agrn}{ }^{-/-}$mice $^{*} p<$ 0.001 , Mann-Whitney test; $n=4$ from two different mice per genotype and counting between 35 and 80 synapses per experiment). Error bars indicate mean \pm SE. $\boldsymbol{d}$, Staining of sections from wild-type cortex for the $\mathrm{GABA}_{\mathrm{A}} \alpha 2$ subunit (green) and agrin (red). The puncta are primarily non-overlapping (merge). Right, High-power view of the boxed area. $\boldsymbol{e}$, Considerable overlap of the punctate staining for the PSD-95 (green) and agrin (red) was observed in control mice. Right, High-power view of the boxed area. Examples for the colocalization between agrin and PSD-95 are indicated by arrowheads; lack of colocalization is shown with an arrow. Scale bars: $\boldsymbol{a}, \boldsymbol{b}, 200 \mathrm{~nm} ; \boldsymbol{d}, \boldsymbol{e}, 10 \mu \mathrm{m}$.

trol mice (Fig. $4 j$ ), the total number of presynaptic terminals in the cortex of $\mathrm{Tg} / \mathrm{agrm}^{-1-}$ mice is $\sim 30 \%$ lower than in controls (Fig. $4 k$ ). Thus, cortices of $\mathrm{Tg} / \mathrm{agrn}^{-1-}$ mice have the same total number of neurons but only $70 \%$ of the number of presynaptic terminals. These results are thus evidence that the number of synapses per neuron is significantly lower in agrin-deficient cortices.
Agrin affects dendrite length and spine number in cortical pyramidal neurons

To examine whether postsynaptic elements were also affected, we analyzed individual pyramidal neurons of the cortex. To this end, neurons were visualized by Golgi staining. As noted in Figure 4, the overall structure of the neurons did not differ between mu- 

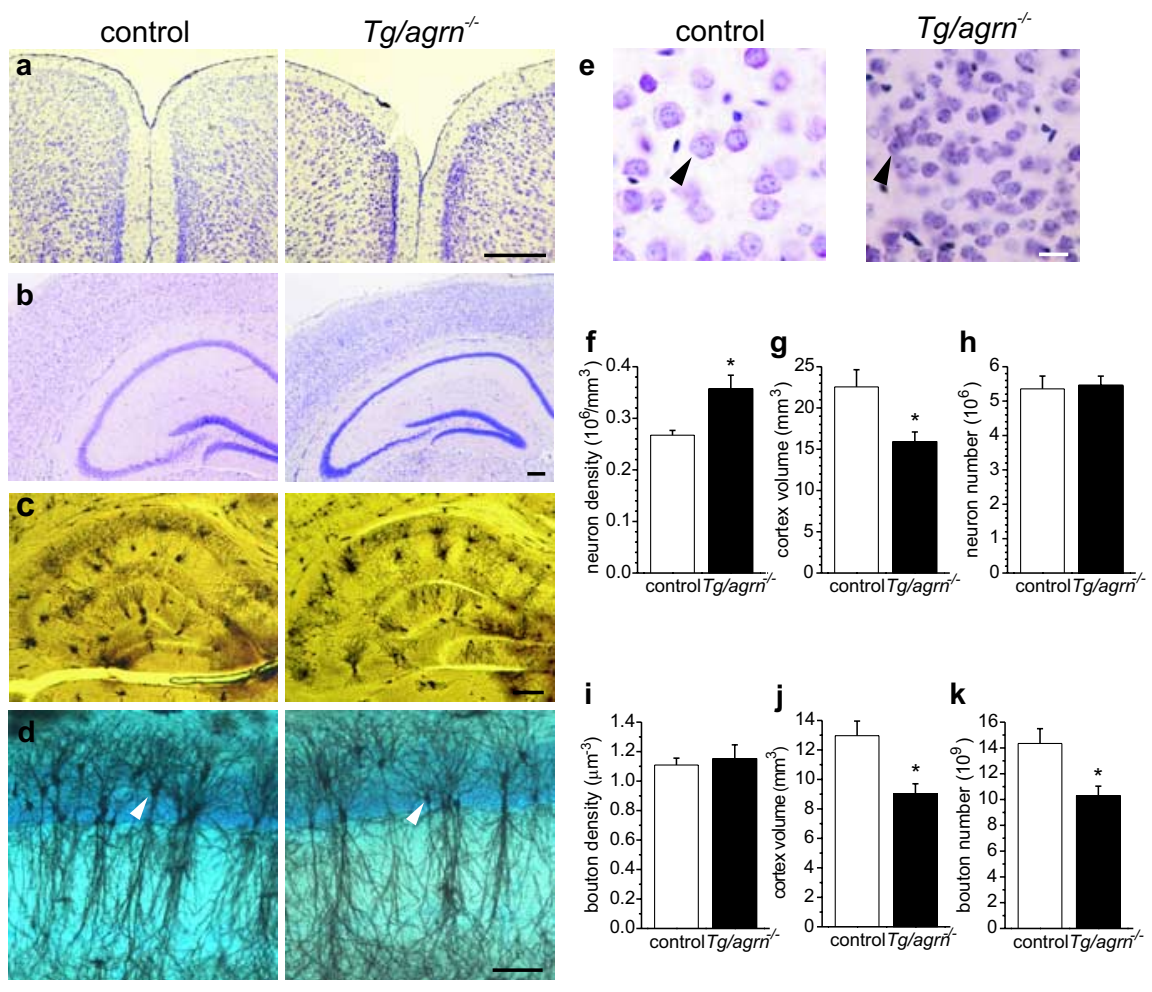

Figure 4. Brain phenotype of adult $\mathrm{Tg} / \mathrm{agrn}{ }^{-1-}$ mice. $\boldsymbol{a}, \boldsymbol{b}$, Cresyl violet staining of cortical hemispheres ( $\boldsymbol{a}$ ) and of cortex and hippocampus (b) does not reveal any overt difference between $\mathrm{Tg}_{\mathrm{agrn}}{ }^{-1-}$ and control mice. $\boldsymbol{c}, \boldsymbol{d}$, Similarly, the gross morphology of the different neuronal cell types was unchanged as observed in Golgi-stained sections from hippocampus. In $\boldsymbol{d}$, CA1 hippocampal neurons (arrows) were stained with Golgi impregnation (black) and cresyl violet (blue). $\boldsymbol{e}$, Neuronal cell bodies were considerably bigger and less packed in control mice compared with $\mathrm{Tg}_{\mathrm{agrn}}{ }^{-1-}$ mice (arrowheads). $\boldsymbol{f}-\boldsymbol{h}$, Stereological quantification of the number of neurons. $\boldsymbol{f}$, The density of neurons is significantly higher in $\mathrm{Tg} / \mathrm{agrn}^{-/-}$than in control mice. $\boldsymbol{g}$, In contrast, the total volume of the cortex is significantly smaller in $\mathrm{Tg}_{\mathrm{agrn}}{ }^{-1-}$ than in control mice. $\boldsymbol{h}$, Based in these two parameters, the number of neurons in the cortex remains constant. $\boldsymbol{i}-\boldsymbol{k}$, Stereological quantification of synapse number after staining for synaptophysin. $\boldsymbol{i}$, The density of synaptic boutons is the same in control and $\mathrm{Tg} / \mathrm{agrn}^{-/-}$mice. $\boldsymbol{j}, \boldsymbol{k}$, Because of the significant decrease in the total volume of the cortex (j), the total number of boutons in the cortices of $\mathrm{Tg}_{\mathrm{agrn}}{ }^{-1-}$ mice decreases by $30 \%$. (k). Asterisks indicate a significant difference between the two groups of mice ( $p$ value at least $<0.02 ; n=5$ or 6 mice for each group). Note that the difference in the cortex volume measured in cresyl violet- and synaptophysin-stained sections is caused by different tissue shrinkage during the experimental procedure. Values in $\boldsymbol{g}, \boldsymbol{h}, \boldsymbol{j}$, and $\boldsymbol{k}$ are calculated for one hemisphere. Error bars indicate mean \pm SE. Scale bars: $\boldsymbol{a}-\boldsymbol{c}, 200 \mu \mathrm{m} ; \boldsymbol{d}, 100 \mu \mathrm{m} ; \boldsymbol{e}, 30 \mu \mathrm{m}$.
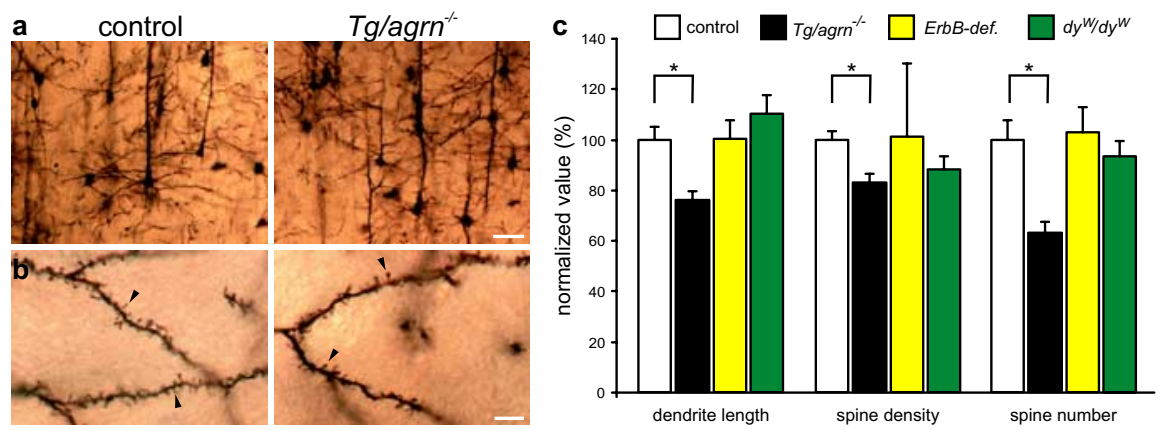

Figure 5. The number of spines is decreased in $\mathrm{Tg} / \mathrm{agrn}^{-/-}$mice but not in other mouse models. $\boldsymbol{a}$, Overall morphology of pyramidal neurons localized to layer II/III of the motor cortex from control and $\mathrm{Tg} / \mathrm{agrn}^{-/-}$mice visualized by Golgi impregnation. $\boldsymbol{b}$, High-magnification images of dendritic spines in which individual spines (arrowheads) can be clearly identified. $\boldsymbol{c}$, Measurement of the total length of the dendrites (dendrite length), average density of spines (spine density), and the total number of spines (spine number) in cortical neurons after reconstruction using a Neurolucida camera (see also supplemental Fig. 2, available at www.jneurosci.org as supplemental material). The values for all these parameters were significantly lower in neurons from $\mathrm{Tg} / \mathrm{agrn}^{-1-}$ mice compared with control mice. In contrast, values do not differ from controls in neurons of mice that are either deficient for ErbB2 and ErbB4 in skeletal muscle (ErbB-def.) or deficient for laminin- $\alpha 2\left(d y^{w} / d y{ }^{W}\right)$. For each genotype, at least three mice were examined, and 10 neurons each were reconstructed. Data represent mean $\pm \operatorname{SE}(n \geq 3)$ where the values of the control mice were set to $100 \%$. Asterisks denote significant differences ( $p<0.01$, Mann-Whitney test). Scale bars: $\boldsymbol{a}, 50 \mu \mathrm{m} ; \boldsymbol{b}$, $10 \mu \mathrm{m}$. See Table 1 for details and for additional parameters. See Material and Methods for experimental details. tants and controls (Fig. 5a). Examination at high power suggested, however, that the density of the spines (Fig. $5 b$, arrowheads) was lower than in control mice. To measure different dendritic parameters and to quantify them, we next reconstructed individual neurons using a Neurolucida camera (see examples in supplemental Fig. 2 , available at www.jneurosci.org as supplemental material). As shown in Figure $5 c$ and in Table 1, dendrite length and spine density was significantly lower in pyramidal neurons from $\mathrm{Tg} / \mathrm{agrn}^{-1-}$ mice. This resulted in a $30 \%$ loss of postsynaptic spines per neuron compared with control mice (Fig. 5c). No significant alterations could be found in the number of primary dendrites, the number of dendritic branching points, and the length of the postsynaptic spines (Table 1). Despite the change in synapse number, the remaining synapses in $\mathrm{Tg} / \mathrm{agrn}^{-1-}$ mice were morphologically indistinguishable from synapses in control littermates, as revealed by electron microscopy (supplemental Fig. 3, available at www.jneurosci.org as supplemental material). Together with the data presented in Figure 4, these results indicate that pyramidal neurons in the cortex of Tg/agrn ${ }^{-1}$ mice have $\sim 30 \%$ less presynaptic and postsynaptic specializations than controls.

To ask whether the changes in synapse number are a direct consequence of agrin deficiency and not secondary to neuromuscular problems, changes in organ size, or overall health, we also measured dendrite length and spine number in pyramidal neurons in the cortex of two additional mouse models. The first model, called $d y^{W} / d y^{W}$, carries a targeted deletion of the lama2 gene and represents a model for MDC1A congenital muscle dystrophy (Kuang et al., 1998). Laminin- $\alpha 2$-like immunoreactivity and its integrin receptors have been localized to spines in hippocampal neurons (Tian et al., 1997; Shi and Ethell, 2006). Moreover, $d y^{2 J} / d y^{2 J}$ mice, which also carry a mutation in the lama2 gene but display a milder form of MDC1A, show deficits in long-term synaptic plasticity in Purkinje cells (Anderson et al., 2005). Most importantly, $d y^{W} / d y^{W}$ mice are small, strongly impaired in their locomotory activity, and often die at the age of $\sim 8$ weeks (Moll et al., 2001). The second mouse model carries a muscle-specific deletion of the two neuregulin receptors ErbB2 and ErbB4 (Escher et al., 2005). These mice weigh $\sim 30 \%$ less than control littermates but have a normal locomotory activity and do not die prematurely. Thus, both of these mouse models reiterate some of the pheno- 
Table 1. Quantification of neuronal complexity

\begin{tabular}{lcc}
\hline & Control & \multicolumn{1}{c}{ Tg/agrn $^{-/-}$} \\
\hline Number of primary dendrites per neuron & $5.6 \pm 0.30$ & $5.5 \pm 0.31$ \\
Branching points per $100 \mu \mathrm{m}$ of dendrite & $1.10 \pm 0.04$ & $1.17 \pm 0.04$ \\
Length of dendrites $(\mu \mathrm{m})$ & $1491 \pm 73$ & $1134 \pm 50^{*}$ \\
Spine length $(\mu \mathrm{m})$ & $1.841 \pm 0.006$ & $1.731 \pm 0.006$ \\
Spine density $\left(\mu \mathrm{m}^{-1}\right)$ & $0.83 \pm 0.028$ & $0.69 \pm 0.028^{*}$ \\
Spine number per dendrite & $401 \pm 30.5$ & $253 \pm 17.6^{*}$
\end{tabular}

Morphology of cortical pyramidal neurons in 7-week-old mice. Values derive from at least three mice of each genotype and the full reconstruction of 10 neurons from each mouse. Values are mean \pm SE. ${ }^{*} p<0.01$ compared with control. For details, see also supplemental Fig. 2 (available at www.jneurosci.org as supplemental material) and Materials and Methods.

types that are also found in the Tg/agrn ${ }^{-1-}$ mice and are therefore appropriate models to check whether the synaptic phenotype observed in $\mathrm{Tg} / \mathrm{agrn}^{-1-}$ mice is a direct consequence of the loss of agrin. As shown in Figure $5 c$, neither the length of the dendrites nor the density of spines in $d y^{W} / d y^{W}$ or ErbB-deficient mice was significantly different from control mice.

\section{Agrin deficiency affects the function of excitatory but not inhibitory synapses}

Because our results strongly indicate that the synapse number in $\mathrm{Tg}_{\mathrm{ggrn}}{ }^{-1-}$ is lower, we next asked whether synaptic functions were affected. To test this, we measured the frequency and amplitude of mEPSC and mIPSC currents of pyramidal neurons in layer II/III of the motor cortex using whole-cell patch-clamp recordings. mEPSCs were recorded in the presence of TTX $(0.5 \mu \mathrm{M})$ and picrotoxin $(100 \mu \mathrm{M})$ to block action potential firing and $\mathrm{GABA}_{\mathrm{A}}$ activity, respectively. mIPSCs were recorded in the presence of TTX and the glutamate receptor antagonist kynurenic acid $(2 \mathrm{~mm})$. As shown in Figure $6 a-c$, we found a significant decrease in the mEPSC frequency in $\mathrm{Tg}_{\mathrm{ggrm}}{ }^{-1-}$ compared with littermate controls, consistent with a decrease in the number of glutamatergic synapses. mEPSCs were completely blocked by the application of $2 \mathrm{~mm}$ kynurenic acid, both in $\mathrm{Tg}_{\text {agrn }}{ }^{-/-}$and control littermates ( $n=5$ and $n=7$ for ${\mathrm{Tg} / \mathrm{agr}{ }^{-/}}^{-}$and control mice, respectively), thus confirming that mEPSCs are mediated by glutamate receptors. The amplitudes of mEPSCs were similar between control and $\mathrm{Tg} / \mathrm{agrn}^{-1-}$ mice (Fig. $6 \mathrm{c}$ ), suggesting that the responsiveness and number of postsynaptic glutamate receptors are not altered. Neither the mean mIPSC frequency (Fig. 6e) nor amplitude (Fig. $6 f$ ) differed between the Tg/agrn ${ }^{-1-}$ and control mice. In both types of mice, mIPSCs were abolished by the application of $100 \mu \mathrm{M}$ picrotoxin, indicating that mIPSCs are mediated by the activation of $\mathrm{GABA}_{\mathrm{A}}$ receptors $\left(n=6\right.$ and $n=5$ for $\mathrm{Tg}_{\mathrm{agrn}}{ }^{-1-}$ and control mice, respectively). In summary, the decrease in the mEPSC frequency and the absence of changes in inhibitory synaptic transmission is consistent with a selective loss of excitatory synapses in $\mathrm{Tg}_{\mathrm{ggrn}}{ }^{-1-}$ mice.

\section{The receptor tyrosine kinase MuSK is localized to CNS synapses}

At the NMJ, the receptor tyrosine kinase MuSK is required for agrin-induced signaling (Glass et al., 1996). Using Northern blot analysis, MuSK is not detected in rat brain (Valenzuela et al., 1995). In contrast, transcripts for MuSK were found in the brain of other species (Ganju et al., 1995; Fu et al., 1999; Garcia-Osta et al., 2006). Because agrin signaling in the brain might be mediated by MuSK, we looked at the expression of MuSK on the mRNA and protein level. Reverse transcription (RT), followed by PCR on RNA isolated from cortices of wild-type mice, revealed a product of the expected size (Fig. $7 a, \mathrm{ctx}$ ). This product was specific because it was absent when the reverse transcriptase was omitted a
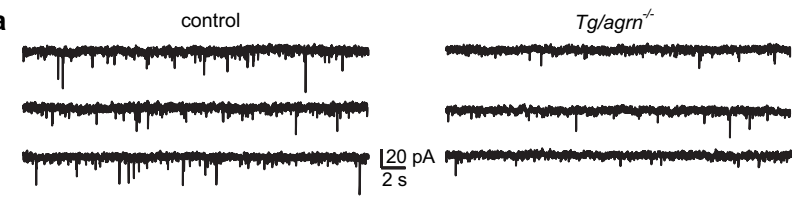

b
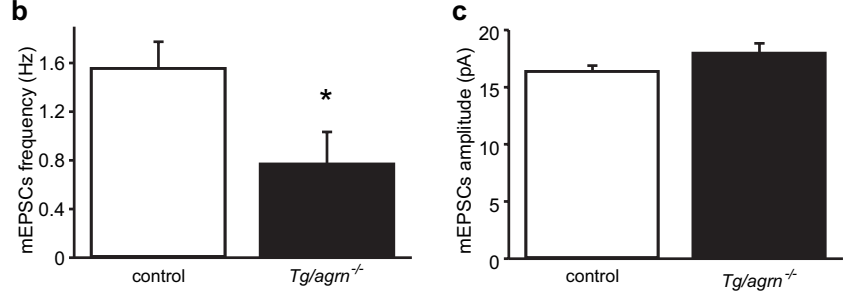

d
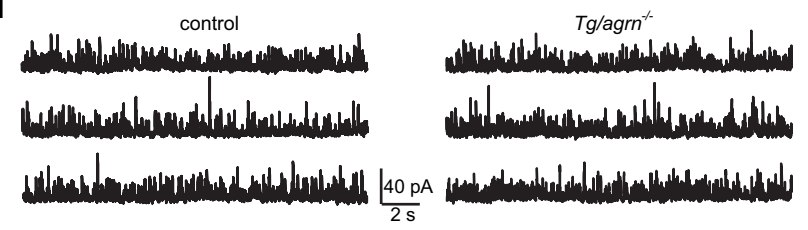

e
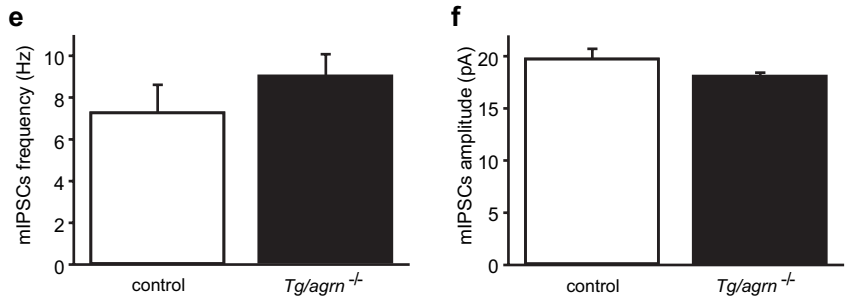

Figure 6. Spontaneous miniature currents recorded in layer II/III pyramidal neurons of the motor cortex from $\mathrm{Tg}_{\text {/agrn }}{ }^{-1-}$ and control littermates. $\boldsymbol{a}$, Representative recordings of pharmacologically isolated mEPSCs in pyramidal neurons of control and $\mathrm{Tg}_{\mathrm{agrn}}{ }^{-/-}$mice. mEPSCs were recorded at a holding potential of $-70 \mathrm{mV}$ in the presence of $1 \mu \mathrm{m}$ TTX and $100 \mu \mathrm{m}$ picrotoxin. $\boldsymbol{b}, \boldsymbol{c}$, The frequency of mEPSCs was significantly reduced in $\mathrm{Tg}_{\mathrm{agrn}}{ }^{-1-}$ mice compared with control littermates (control: $1.56 \pm 0.22 \mathrm{~Hz}, n=17 ; \mathrm{Tg} \mathrm{agrn}^{-1-}: 0.77 \pm 0.26 \mathrm{~Hz}$, $n=12 ; p<0.05$, ANOVA test). In contrast, the amplitude of the mEPSCs did not differ between control (16.42 $\pm 0.47 \mathrm{pA} ; n=17)$ and $\mathrm{Tg}$ agrn $^{-/-}(17.99 \pm 0.85 \mathrm{pA} ; n=12)$ mice. $\boldsymbol{d}$, Representative $\mathrm{mIPSC}$ recorded in control and $\mathrm{Tg}_{\text {agrn }}{ }^{-/-}$mice at a holding potential of $0 \mathrm{mV}$ and in the presence of $1 \mu \mathrm{M}$ TTX and 2 mm kynurenic acid. $\boldsymbol{e}, \boldsymbol{f}$, Neither the frequency nor the amplitude of the mIPSCS was changed between controls (frequency, $7.28 \pm 1.13 \mathrm{~Hz}$; amplitude, $19.77 \pm 0.94 \mathrm{pA} ; n=12$ ) and $\mathrm{Tg}_{\mathrm{agrn}}{ }^{-/-}$mice (frequency, $8.99 \pm 1.21 \mathrm{~Hz}$; amplitude, $18.12 \pm 0.31 \mathrm{pA} ; n=12$ ). Control mice were always littermates of $\mathrm{Tg} / \mathrm{agrn}^{-1-}$ mice. Data are represented as means $\pm \mathrm{SE}$.

(Fig. $7 a$, neg) and was also detected in skeletal muscle (Fig. $7 a$, $\mathrm{sm})$. Using a newly raised antiserum against the extracellular domain of mouse MuSK, which recognizes MuSK in Western blots and immunohistochemistry (supplemental Fig. 4, available at www.jneurosci.org as supplemental material) (Scotton et al., 2006), we detected MuSK-like protein in fractions enriched for membranes in brains of wild-type mice (Fig. 7b). In contrast, preimmune serum did not detect any such band. In cross sections from the cortex of wild-type mice, MuSK-like protein was detected as puncta (Fig. 7c). Importantly, these MuSK-positive puncta partially overlapped with puncta positive for PSD-95 (Fig. $7 c$, yellow color in the merged images). Preimmune serum did not stain (Fig. 7d). Quantitative assessment showed that $14.6 \pm$ $1.9 \%$ (mean $\pm \mathrm{SE} ; n=8$ ) of the PSD-95-positive puncta were also positive for MuSK and that $23.0 \pm 3.0 \%$ (mean $\pm \mathrm{SE} ; n=8$ ) of the MuSK-positive puncta were also positive for PSD-95. In contrast, preimmune serum hardly stained any puncta $(\sim 10$ times fewer than immune serum), and of those, only $2.4 \pm 0.7 \%$ overlapped with PSD-95. Because the anti-agrin and anti-MuSK antibodies were both raised in rabbits, we could not perform 
a

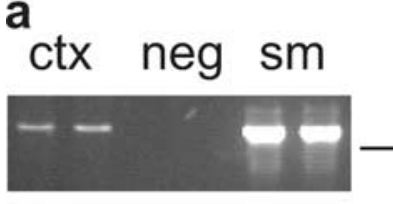

c PSD-95
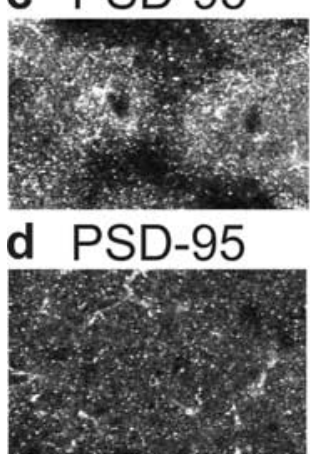

b
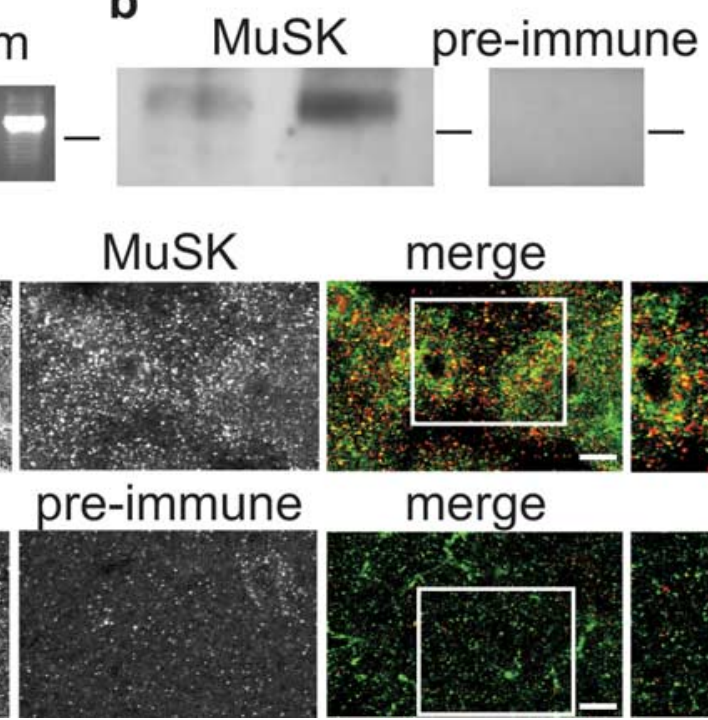

merge

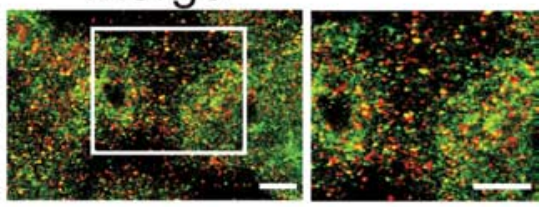

merge

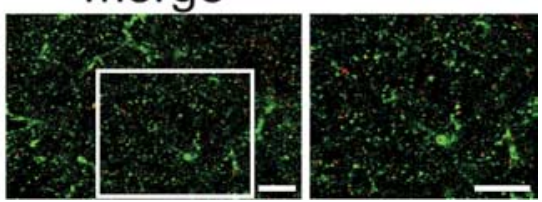

Figure 7. MuSK is expressed in the brain and is localized to a subset of excitatory synapses. $\boldsymbol{a}, \mathrm{RT}-\mathrm{PCR}$ of RNA from cortex (ctx), negative control (neg), and skeletal muscles (sm) of adult mice. MuSK mRNA is clearly detected in mouse cortex although at lower levels than in skeletal muscle. $\boldsymbol{b}$, In Western blot analysis of $\mathrm{P} 2$ brain membranes, anti-MuSK antiserum but not preimmune serum detects a protein with an apparent $M_{\mathrm{r}}$ of $115 \mathrm{kDa}$. Lines indicate $100 \mathrm{kDa}$ marker band. $c$, Sections from wild-type cortex stained for MuSK (red) and PSD-95 (green). MuSK partially colocalizes with PSD-95-positive synapses (merge; yellow). Right, Higherpower view of the boxed area. $\boldsymbol{d}$, No specific signal was detectable in cortical sections from wild-type mice that were stained with MuSK preimmune serum (red) and PSD-95 (green). Right, Higher-power view of the boxed area. Scale bars, $20 \mu \mathrm{m}$.

colocalization studies. The finding that agrin (Fig. 3e) and MuSK both colocalize with PSD-95 suggests, however, that they probably also colocalize. We additionally tried to detect the two homologs of MuSK, Ror1, and Ror2, but the commercial antibodies were not sensitive enough to detect any staining (data not shown).

\section{Alterations in the MAP kinase pathway}

To get some understanding of the molecular mechanisms that may underlie the synaptic changes in the cortex, we next quantified the amount of synaptic marker proteins in the cortices of control and $\mathrm{Tg}_{\mathrm{agrn}}{ }^{-1-}$ mice. In 7-week-old mice, no change in expression levels of markers for inhibitory synapses, such as the $\alpha 1$ subunit and gephyrin was observed (Fig. 8a). Similarly, the amount of the NMDA receptor subunit NR1, of PSD-95, and of CAMKII was not changed (Fig. $8 a$ ). In strong contrast, a substantial increase of the synaptic GTPase-activating protein SynGAP was detected (Fig. 8b). Interestingly, SynGAP levels were not altered in cortices isolated from $d y^{W} / d y^{W}$ mice, consistent with the lack of synaptic phenotype in these mice. The increase in SynGAP levels of $\mathrm{Tg} / \mathrm{agrn}^{-1-}$ mice was even more pronounced in fractions enriched for synaptic membranes (Fig. 8b), indicating that these alteration are synapse specific.

To avoid any bias in our approach, we also examined gene expression in cortices of 4 -week-old control and $\mathrm{Tg}_{\text {/agrn }}{ }^{-1-}$ mice on a genome-wide scale using the Affymetrix Mouse Genome 4302.0 Array. Of the $>39,000$ transcripts, 255 were significantly regulated at least twofold (supplemental Table 1, available at www.jneurosci.org as supplemental material). The majority of the regulated genes falls into the class of signal transduction, followed by genes involved in cell communication (Fig. $8 c$ ). The fact that most of the gene families are represented in the 255 genes suggests that agrin affects many pathways. Moreover, agrin deficiency is likely to influence gene expression not only in neurons but also in non-neuronal cells (e.g., glial cells and blood vessels).
One of the candidates identified, MKK7, has been shown to be involved in agrin signaling at the NMJ (Lacazette et al., 2003). Moreover, the MAP kinase pathway has been implicated in the response of cultured neurons to agrin (Karasewski and Ferreira, 2003; Hilgenberg and Smith, 2004). We therefore concentrated our work on characterizing this pathway. The amount of MKK7 on the mRNA (data not shown) and the protein level was considerably lower in brain extracts from $\mathrm{Tg} /$ $a_{g r n}{ }^{-1-}$ mice than in control or $d y^{W} / d y^{W}$ mice (Fig. 8d). Moreover, the JNK, which is the main substrate for MKK7, became phosphorylated in cultured hippocampal neurons by the addition of neural agrin (data not shown). In summary, these results strongly suggest that agrin can activate the MAP kinase pathway in neurons and that the lack of agrin deregulates this pathway through changes of some of its regulators, such as SynGAP and MKK7.

\section{Discussion}

We show that transgenic expression of neural agrin in motor neurons in agrindeficient mice is sufficient to assemble a functional NMJ and to prevent perinatal death. Thus, agrin expressed by the muscle is not required for the formation of functional NMJs. We observed, however, that the extent to which NMJs were restored greatly differed between individual muscles. Because we did not detect differences in the levels of expression of the transgene between the motor neurons innervating the different muscles (I. Ksiazek and M. A. Ruegg, unpublished observation), our results suggest that there are muscle-intrinsic differences that influence their response to neural agrin. Interestingly, the muscles where synapses were not well restored (such as soleus and diaphragm) were those that have recently been found to be "delayed synapsing" (Pun et al., 2002). Thus, differential responsiveness to neural agrin might be the basis for the phenomenon of delayed synapsing during muscle innervation in the embryo.

Agrin deficiency affects excitatory but not inhibitory synapses In our current work, we focus on the phenotype of $\mathrm{Tg} / \mathrm{agrn}^{-1-}$ mice in the brain. We find a highly significant loss of synapses in the cortex. This conclusion is based on the decrease in the total number of presynaptic terminals detected in cortex (Fig. 4) and a decrease in the density of postsynaptic spines and the length of dendrites (Fig. 5). This loss in synapses is unlikely attributable to the smaller size or the premature death of the $\mathrm{Tg}_{\mathrm{ggrn}}{ }^{-1}$ mice because synapse number was not changed in the cortex of $d y^{W} / d y^{W}$ or ErbB-deficient mice (Fig. 5). Importantly, our electrophysiological studies on acute cortical slices show that the frequency but not the amplitude of mEPSCs is strongly altered in $\mathrm{Tg}_{\mathrm{agrn}}{ }^{-/}$mice. In contrast, the mIPSC frequency and amplitudes remain normal in $\mathrm{Tg}_{\mathrm{ggrm}}{ }^{-1-}$ mice, revealing that functional alterations are confined to excitatory synapses.

The presumed loss of excitatory synapses in the agrindeficient mice, as observed with electrophysiology, is also consistent with the localization of agrin to excitatory (PSD-95 positive) but not inhibitory synapses in wild-type mice (Fig. 3). These 
a

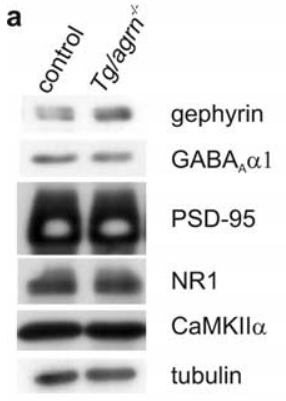

c

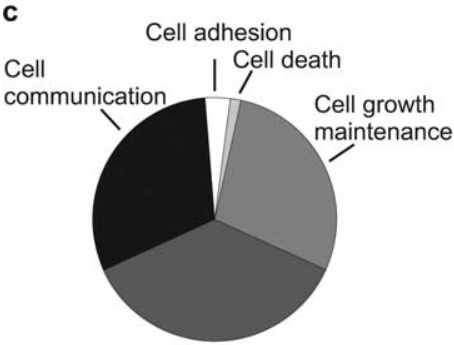

Signal transduction

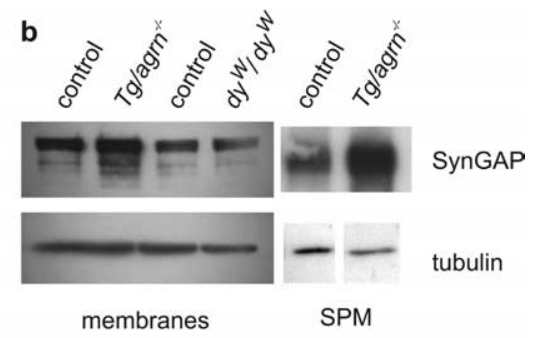

d

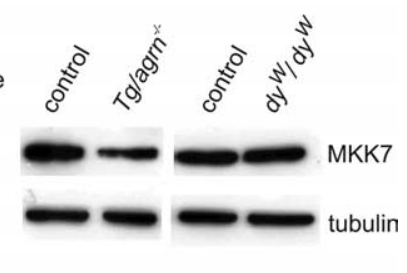

Figure 8. Agrin affects the MAP kinase pathway. $\boldsymbol{a}$, Western blot analysis from P2 membranes isolated from cortices of 6- to 7-week-old mice. No change in the levels of several synaptic proteins was observed. $\boldsymbol{b}$, Compared with wild-type controls, the amount of SynGAP was higher in P2 membrane fractions and in fractions enriched for synaptic membranes (SPM) isolated from cortices of $\mathrm{Tg}_{\mathrm{aggrn}}{ }^{-1-}$ mice. Such change was not detected in $d \mathrm{y}^{W} / d \mathrm{y}^{W}$ mice. $\mathrm{c}$, GeneChip analysis on cortices from 4-week-old control and $\mathrm{Tg}_{\text {/agrn }}{ }^{-/-}$mice. Genes with at least twofold altered expression levels in $\mathrm{Tg} / \mathrm{agrn}^{-1-}$ compared with controls are classified into groups by their biological function. $d$, MKK7 is downregulated in Tg/agrn ${ }^{-/-}$but not in $d y^{W} / d y^{W}$ mice.

results were unexpected because previous antisense experiments provided evidence for a role of agrin at inhibitory synapses (Ferreira, 1999). In addition, $\alpha$-dystroglycan, which is probably the most abundant agrin-binding protein (Gesemann et al., 1998), colocalizes with a subset of $\mathrm{GABA}_{\mathrm{A}}$ receptors (Brunig et al., 2002; Levi et al., 2002). Thus, the finding that agrin does not colocalize with inhibitory synapses and that deletion of the agrin gene does not affect the function of inhibitory synapses strongly suggests that the binding of agrin to $\alpha$-dystroglycan might be compensated for by other $\alpha$-dystroglycan-binding molecules of the extracellular matrix, in particular by the neurexins (Sugita et al., 2001), perlecan, or the laminins (Talts et al., 1999). Our observation that the pial basement membrane, the glia limitans, and the laminar structures of the cortex are also not affected in $\mathrm{Tg} /$ $\mathrm{agrn}^{-/-}$mice is consistent with such a compensatory mechanism because brain-specific inactivation of $\alpha$-dystroglycan disrupts these structures (Moore et al., 2002).

\section{Receptors that may mediate agrin signaling}

There are several candidate receptors for agrin in the CNS. One of those is the receptor tyrosine kinase MuSK that mediates the postsynapse-inducing activity of agrin at the NMJ. We find that MuSK is also expressed in cortex and that the protein, like agrin, partially overlaps with PSD-95-positive puncta (Fig. 7). Our data are also supported by the recent report showing that MuSK is expressed in brain (Garcia-Osta et al., 2006). At the NMJ, MuSK can only be activated by agrin splice variants that are released from the nerve terminal (called neural agrin) but not by those synthesized by non-neuronal tissue including muscle (called non-neuronal or muscle agrin), which are also inactive in inducing AChR aggregation (for review, see Bezakova and Ruegg,

2003). Previous work has shown that mRNA encoding neural agrin is expressed in noncholinergic neurons of the brain (O'Connor et al., 1994; Stone and Nikolics, 1995). Thus, it may well be that the loss of synapses in the cortex of $\mathrm{Tg}_{\mathrm{ggrn}}{ }^{-1-}$ mice is only attributable to the loss of neural agrin. Consistent with the possibility that agrin could signal through MuSK, knock-down of MuSK expression by antisense oligonucleotides in rat brain leads to impairment of memory consolidation and of the induction and maintenance of long-term potentiation (Garcia-Osta et al., 2006). This activity of MuSK appears to involve phosphorylation of CREB and upregulation of expression of CCAAT enhancerbinding protein $\beta$. Phosphorylation of CREB has been shown to be induced only by neural but not by non-neuronal forms of agrin (Ji et al., 1998), and it is known to be downstream of the MAP kinase pathway (for review, see Thomas and Huganir, 2004), which is also perturbed in the cortex of $\mathrm{Tg}_{\mathrm{agrn}}{ }^{-/-}$mice (see discussion below). Thus, our results would be in agreement with the possibility that agrin also acts via MuSK at excitatory synapses in the brain.

Other candidate receptors that have been suggested to mediate agrin signaling in the brain are the two MuSK homologs Ror 1 and Ror2, which are both highly expressed in developing and adolescent brain (Yoda et al., 2003). Our own attempts to localize Ror1 and Ror2 to synapses in the mouse brain were not successful (data not shown), which might be because of low sensitivity of the antibodies used. No gross morphological abnormalities in the nervous system were observed for Ror1- or Ror2-deficient mice (Yoda et al., 2003). In addition, Ror1 and Ror2 are rather enriched at growth cones than at synapses in developing hippocampal neurons (Paganoni and Ferreira, 2003), and they have been implicated in affecting neurite outgrowth (Paganoni and Ferreira, 2005). Finally, Ror2 was shown to be involved in the formation of filopodia induced by wnt5a (Nishita et al., 2006). Thus, the current data make MuSK a more likely candidate receptor for agrin than Ror1 or Ror2.

Another particularly attractive candidate receptor for agrin is the $\alpha 3$ subunit of the $\mathrm{Na}^{+} / \mathrm{K}^{+}$-ATPase (NKA) that was recently shown to bind both neural and non-neuronal splice variants of agrin (Hilgenberg et al., 2006). The $\alpha 3$ subunit of NKA is localized to synapses in cultured cortical neurons, and agrin binding to $\alpha 3$ NKA inhibits its function and therefore causes a slight depolarization of the cell. Thus, the lack of agrin could result in reduced neuronal activity and reduced responsiveness of neurons to excitatory input. The fact that we find a strong decrease in the frequency of the mEPSC but not the MIPSC would then suggest that the function of agrin to antagonize $\alpha 3 \mathrm{NKA}$ is selective for excitatory synapses or that $\alpha 3 \mathrm{NKA}$ expression is restricted to excitatory synapses. Whether an increased activity of $\alpha 3 \mathrm{NKA}$ because of the lack of its endogenous antagonist agrin will result in a lower number of synapses remains unknown.

\section{Agrin deficiency deregulates MAP kinase signaling}

Several lines of evidence suggest that agrin activates the MAP kinase pathway in cultured neurons (Karasewski and Ferreira, 2003; Hilgenberg and Smith, 2004). Moreover, one of its downstream targets, CREB, becomes phosphorylated after the addition of agrin (Ji et al., 1998). We now find strong evidence that MAP kinase signaling is indeed altered in the brain of $\mathrm{Tg}_{\mathrm{g}} \mathrm{agrn}^{-1-}$ mice because they show a strong increase in the amount of the Ras GTPase-activating protein SynGAP and a reduction in MKK7 mRNA and protein. SynGAP has been shown to dampen MAP kinase signaling (Komiyama et al., 2002), and neurons cultured from SynGAP-deficient mice have more AMPA receptor clusters (Kim et al., 2003). Interestingly, transfection of constructs encod- 
ing green fluorescent protein-SynGAP into neuronal cultures causes a strong decrease in the frequency of the mEPSCs and a dampening of extracellular signal-regulated kinase (ERK) activation compared with control cultures. Conversely, SynGAPdeficient neurons show an increase in the frequency of the mEPSCs and increased ERK activation (Rumbaugh et al., 2006). Thus, upregulation of SynGAP in the $\mathrm{Tg} / \mathrm{agrn}^{-/-}$mice could lower the activity of MAP kinases and subsequently result in less synapses. Similarly, the decrease in MKK7, which is also highly enriched in postsynaptic density fractions (Collins et al., 2005), is likely to dampen signaling via the MAP kinase.

Although it is unknown how agrin activates MAP kinase signaling in the brain, we have recently found that both ERK and JNK are phosphorylated at the NMJ or at ectopic postsynaptic structures induced by the injection of recombinant agrin into muscle (G. Bezakova and Ruegg, unpublished data). Importantly, phosphorylation of JNK and ERK at the NMJ is a direct consequence of the activation of MuSK by agrin because it does not require ErbB-signaling (Bezakova and Ruegg, unpublished data). Thus, the capability of agrin to activate MAP kinase signaling in neurons could also be mediated by MuSK. Alternatively, binding of agrin to $\alpha 3 \mathrm{NKA}$ could trigger $\mathrm{Ca}^{2+}$ signaling in neurons (Hilgenberg et al., 2006), which in turn can activate the MAP kinase pathway.

\section{Other pathways that might be regulated by agrin}

Our gene expression studies in Tg/agrn ${ }^{-1-}$ mice show that expression of the GTPase-activating RANGAP domain-like 1 protein (also called TULIP1 or GARNL1 (Schwarzbraun et al., 2004) is increased by $>20$-fold. Although the function of GARNL1 is not known, it is highly expressed in brain, and it is a close homolog of tuberous sclerosis complex (TSC) 1 and TSC2. TSC1/2 have been shown to control cell size by inhibiting the mammalian target of rapamycin (mTOR) pathway (Inoki et al., 2005). The annotated gene, the expression level of which is $>20$-fold lower in $\mathrm{Tg} / \mathrm{agrn}^{-1-}$ mice than in control mice, is the ribosomal protein S6, a substrate of S6 kinase 1, which is activated by mTOR. These results suggest that agrin deficiency might affect protein translation via the mTOR pathway. Changes in protein synthesis might be the reason for the smaller size of the neurons in $\mathrm{Tg} / \mathrm{agrn}^{-1-}$ mice.

In conclusion, our work provides for the first time evidence that agrin does play a role in the formation and/or maintenance of CNS synapses in vivo. The synaptic deficits are detectable only in adolescent and adult mice, whereas neurons from agrindeficient mice still form synapses in culture (Li et al., 1999; Serpinskaya et al., 1999) and the brain of agrin-deficient embryos have no synaptic defects (Gautam et al., 1996). Interestingly, a similar situation was reported for the development of the NMJ, where AChR clusters form in cultured myotubes independent of agrin and where AChR clusters are detected in embryos that are deficient for agrin, or where innervation of the muscle by the motor neuron has been prevented by genetic ablation (Lin et al., 2001; Yang et al., 2001). Thus, in both systems, the function of agrin at synapses may become only apparent when synapses are fully functional.

\section{References}

Akins MR, Biederer T (2006) Cell-cell interactions in synaptogenesis. Curr Opin Neurobiol 16:83-89.

Anderson JL, Head SI, Morley JW (2005) Synaptic plasticity in the dy2J mouse model of laminin alpha2-deficient congenital muscular dystrophy. Brain Res 1042:23-28.

Arber S, Han B, Mendelsohn M, Smith M, Jessell TM, Sockanathan S (1999)
Requirement for the homeobox gene $\mathrm{Hb} 9$ in the consolidation of motor neuron identity. Neuron 23:659-674.

Barber AJ, Lieth E (1997) Agrin accumulates in the brain microvascular basal lamina during development of the blood-brain barrier. Dev Dyn 208:62-74.

Bezakova G, Lomo T (2001) Muscle activity and muscle agrin regulate the organization of cytoskeletal proteins and attached acetylcholine receptor (AchR) aggregates in skeletal muscle fibers. J Cell Biol 153:1453-1463.

Bezakova G, Ruegg MA (2003) New insights into the roles of agrin. Nat Rev Mol Cell Biol 4:295-308.

Bezakova G, Helm JP, Francolini M, Lomo T (2001) Effects of purified recombinant neural and muscle agrin on skeletal muscle fibers in vivo. J Cell Biol 153:1441-1452.

Bose CM, Qiu D, Bergamaschi A, Gravante B, Bossi M, Villa A, Rupp F, Malgaroli A (2000) Agrin controls synaptic differentiation in hippocampal neurons. J Neurosci 20:9086-9095.

Brewer GJ, Torricelli JR, Evege EK, Price PJ (1993) Optimized survival of hippocampal neurons in B27-supplemented Neurobasal, a new serumfree medium combination. J Neurosci Res 35:567-576.

Brunig I, Scotti E, Sidler C, Fritschy JM (2002) Intact sorting, targeting, and clustering of gamma-aminobutyric acid A receptor subtypes in hippocampal neurons in vitro. J Comp Neurol 443:43-55.

Burgess RW, Nguyen QT, Son YJ, Lichtman JW, Sanes JR (1999) Alternatively spliced isoforms of nerve- and muscle-derived agrin: their roles at the neuromuscular junction. Neuron 23:33-44.

Burgess RW, Skarnes WC, Sanes JR (2000) Agrin isoforms with distinct amino termini. Differential expression, localization, and function. J Cell Biol 151:41-52.

Calhoun ME, Kurth D, Phinney AL, Long JM, Hengemihle J, Mouton PR, Ingram DK, Jucker M (1998) Hippocampal neuron and synaptophysinpositive bouton number in aging C57BL/6 mice. Neurobiol Aging 19:599-606.

Cohen I, Rimer M, Lomo T, McMahan UJ (1997) Agrin-induced postsynaptic apparatus in skeletal muscle fibers in vivo. Mol Cell Neurosci 9:237-253.

Collins MO, Husi H, Yu L, Brandon JM, Anderson CN, Blackstock WP, Choudhary JS, Grant SG (2006) Molecular characterization and comparison of the components and multiprotein complexes in the postsynaptic proteome. J Neurochem 97 ]Suppl 1]:16-23.

Costell M, Gustafsson E, Aszodi A, Morgelin M, Bloch W, Hunziker E, Addicks K, Timpl R, Fassler R (1999) Perlecan maintains the integrity of cartilage and some basement membranes. J Cell Biol 147:1109-1122.

Denzer AJ, Schulthess T, Fauser C, Schumacher B, Kammerer RA, Engel J, Ruegg MA (1998) Electron microscopic structure of agrin and mapping of its binding site in laminin-1. EMBO J 17:335-343.

Escher P, Lacazette E, Courtet M, Blindenbacher A, Landmann L, Bezakova G, Lloyd KC, Mueller U, Brenner HR (2005) Synapses form in skeletal muscles lacking neuregulin receptors. Science 308:1920-1923.

Eusebio A, Oliveri F, Barzaghi P, Ruegg MA (2003) Expression of mouse agrin in normal, denervated and dystrophic muscle. Neuromuscul Disord 13:408-415.

Ferreira A (1999) Abnormal synapse formation in agrin-depleted hippocampal neurons. J Cell Sci 112:4729-4738.

Fritschy JM, Weinmann O, Wenzel A, Benke D (1998) Synapse-specific localization of NMDA and GABA(A) receptor subunits revealed by antigen-retrieval immunohistochemistry. J Comp Neurol 390:194-210.

Fu AK, Smith FD, Zhou H, Chu AH, Tsim KW, Peng BH, Ip NY (1999) Xenopus muscle-specific kinase: molecular cloning and prominent expression in neural tissues during early embryonic development. Eur J Neurosci 11:373-382.

Ganju P, Walls E, Brennan J, Reith AD (1995) Cloning and developmental expression of Nsk2, a novel receptor tyrosine kinase implicated in skeletal myogenesis. Oncogene 11:281-290.

Garcia-Osta A, Tsokas P, Pollonini G, Landau EM, Blitzer R, Alberini CM (2006) MuSK expressed in the brain mediates cholinergic responses, synaptic plasticity, and memory formation. J Neurosci 26:7919-7932.

Gautam M, Noakes PG, Moscoso L, Rupp F, Scheller RH, Merlie JP, Sanes JR (1996) Defective neuromuscular synaptogenesis in agrin-deficient mutant mice. Cell 85:525-535.

Gesemann M, Denzer AJ, Ruegg MA (1995) Acetylcholine receptoraggregating activity of agrin isoforms and mapping of the active site. J Cell Biol 128:625-636. 
Gesemann M, Brancaccio A, Schumacher B, Ruegg MA (1998) Agrin is a high-affinity binding protein of dystroglycan in non-muscle tissue. J Biol Chem 273:600-605.

Gingras J, Rassadi S, Cooper E, Ferns M (2002) Agrin plays an organizing role in the formation of sympathetic synapses. J Cell Biol 158:1109-1118.

Glass DJ, Bowen DC, Stitt TN, Radziejewski C, Bruno J, Ryan TE, Gies DR, Shah S, Mattsson K, Burden SJ, DiStefano PS, Valenzuela DM, DeChiara TM, Yancopoulos GD (1996) Agrin acts via a MuSK receptor complex. Cell 85:513-523.

Halfter W, Schurer B, Yip J, Yip L, Tsen G, Lee JA, Cole GJ (1997) Distribution and substrate properties of agrin, a heparan sulfate proteoglycan of developing axonal pathways. J Comp Neurol 383:1-17.

Halfter W, Dong S, Yip YP, Willem M, Mayer U (2002) A critical function of the pial basement membrane in cortical histogenesis. J Neurosci 22:6029-6040.

Hausser HJ, Ruegg MA, Brenner RE, Ksiazek I (2006) Agrin is highly expressed by chondrocytes and is required for normal growth. Histochem Cell Biol 127:363-374.

Hilgenberg LG, Smith MA (2004) Agrin signaling in cortical neurons is mediated by a tyrosine kinase-dependent increase in intracellular $\mathrm{Ca} 2+$ that engages both CaMKII and MAPK signal pathways. J Neurobiol 61:289-300.

Hilgenberg LG, Hoover CL, Smith MA (1999) Evidence of an agrin receptor in cortical neurons. J Neurosci 19:7384-7393.

Hilgenberg LG, Ho KD, Lee D, O’Dowd DK, Smith MA (2002) Agrin regulates neuronal responses to excitatory neurotransmitters in vitro and in vivo. Mol Cell Neurosci 19:97-110.

Hilgenberg LG, Su H, Gu H, O’Dowd DK, Smith MA (2006) Alpha3Na+/ $\mathrm{K}+$-ATPase is a neuronal receptor for agrin. Cell 125:359-369.

Inoki K, Corradetti MN, Guan KL (2005) Dysregulation of the TSC-mTOR pathway in human disease. Nat Genet 37:19-24.

Ji RR, Bose CM, Lesuisse C, Qiu D, Huang JC, Zhang Q, Rupp F (1998) Specific agrin isoforms induce cAMP response element binding protein phosphorylation in hippocampal neurons. J Neurosci 18:9695-9702.

Jones DH, Matus AI (1974) Isolation of synaptic plasma membrane from brain by combined flotation-sedimentation density gradient centrifugation. Biochim Biophys Acta 356:276-287.

Jones G, Meier T, Lichtsteiner M, Witzemann V, Sakmann B, Brenner HR (1997) Induction by agrin of ectopic and functional postsynaptic-like membrane in innervated muscle. Proc Natl Acad Sci USA 94:2654-2659.

Karasewski L, Ferreira A (2003) MAPK signal transduction pathway mediates agrin effects on neurite elongation in cultured hippocampal neurons. J Neurobiol 55:14-24.

Kim E, Sheng M (2004) PDZ domain proteins of synapses. Nat Rev Neurosci 5:771-781.

Kim JH, Lee HK, Takamiya K, Huganir RL (2003) The role of synaptic GTPase-activating protein in neuronal development and synaptic plasticity. J Neurosci 23:1119-1124.

Komiyama NH, Watabe AM, Carlisle HJ, Porter K, Charlesworth P, Monti J, Strathdee DJ, O'Carroll CM, Martin SJ, Morris RG, O’Dell TJ, Grant SG (2002) SynGAP regulates ERK/MAPK signaling, synaptic plasticity, and learning in the complex with postsynaptic density 95 and NMDA receptor. J Neurosci 22:9721-9732.

Kuang W, Xu H, Vachon PH, Liu L, Loechel F, Wewer UM, Engvall E (1998) Merosin-deficient congenital muscular dystrophy. Partial genetic correction in two mouse models. J Clin Invest 102:844-852.

Lacazette E, Le Calvez S, Gajendran N, Brenner HR (2003) A novel pathway for MuSK to induce key genes in neuromuscular synapse formation. J Cell Biol 161:727-736.

Levi S, Grady RM, Henry MD, Campbell KP, Sanes JR, Craig AM (2002) Dystroglycan is selectively associated with inhibitory GABAergic synapses but is dispensable for their differentiation. J Neurosci 22:4274-4285.

Li Z, Hilgenberg LG, O’Dowd DK, Smith MA (1999) Formation of functional synaptic connections between cultured cortical neurons from agrin-deficient mice. J Neurobiol 39:547-557.

Lin W, Burgess RW, Dominguez B, Pfaff SL, Sanes JR, Lee KF (2001) Distinct roles of nerve and muscle in postsynaptic differentiation of the neuromuscular synapse. Nature 410:1057-1064.

Matzilevich DA, Rall JM, Moore AN, Grill RJ, Dash PK (2002) High-density microarray analysis of hippocampal gene expression following experimental brain injury. J Neurosci Res 67:646-663.
McMahan UJ (1990) The agrin hypothesis. Cold Spring Harb Symp Quant Biol 55:407-418.

Miner JH, Cunningham J, Sanes JR (1998) Roles for laminin in embryogenesis: exencephaly, syndactyly, and placentopathy in mice lacking the laminin alpha5 chain. J Cell Biol 143:1713-1723.

Moll J, Barzaghi P, Lin S, Bezakova G, Lochmuller H, Engvall E, Muller U, Ruegg MA (2001) An agrin minigene rescues dystrophic symptoms in a mouse model for congenital muscular dystrophy. Nature 413:302-307.

Moore SA, Saito F, Chen J, Michele DE, Henry MD, Messing A, Cohn RD, Ross-Barta SE, Westra S, Williamson RA, Hoshi T, Campbell KP (2002) Deletion of brain dystroglycan recapitulates aspects of congenital muscular dystrophy. Nature 418:422-425.

Neumann FR, Bittcher G, Annies M, Schumacher B, Kroger S, Ruegg MA (2001) An alternative amino-terminus expressed in the central nervous system converts agrin to a type II transmembrane protein. Mol Cell Neurosci 17:208-225.

Nishita M, Yoo SK, Nomachi A, Kani S, Sougawa N, Ohta Y, Takada S, Kikuchi A, Minami Y (2006) Filopodia formation mediated by receptor tyrosine kinase Ror2 is required for Wnt5a-induced cell migration. J Cell Biol 175:555-562.

O'Connor LT, Lauterborn JC, Gall CM, Smith MA (1994) Localization and alternative splicing of agrin mRNA in adult rat brain: transcripts encoding isoforms that aggregate acetylcholine receptors are not restricted to cholinergic regions. J Neurosci 14:1141-1152.

Paganoni S, Ferreira A (2003) Expression and subcellular localization of Ror tyrosine kinase receptors are developmentally regulated in cultured hippocampal neurons. J Neurosci Res 73:429-440.

Paganoni S, Ferreira A (2005) Neurite extension in central neurons: a novel role for the receptor tyrosine kinases Ror1 and Ror2. J Cell Sci 118:433-446.

Pun S, Sigrist M, Santos AF, Ruegg MA, Sanes JR, Jessell TM, Arber S, Caroni $P$ (2002) An intrinsic distinction in neuromuscular junction assembly and maintenance in different skeletal muscles. Neuron 34:357-370.

Reist NE, Magill C, McMahan UJ (1987) Agrin-like molecules at synaptic sites in normal, denervated, and damaged skeletal muscles. J Cell Biol 105:2457-2469.

Rumbaugh G, Adams JP, Kim JH, Huganir RL (2006) SynGAP regulates synaptic strength and mitogen-activated protein kinases in cultured neurons. Proc Natl Acad Sci USA 103:4344-4351.

Sanes JR, Lichtman JW (2001) Induction, assembly, maturation and maintenance of a postsynaptic apparatus. Nat Rev Neurosci 2:791-805.

Schwarzbraun T, Vincent JB, Schumacher A, Geschwind DH, Oliveira J, Windpassinger C, Ofner L, Ledinegg MK, Kroisel PM, Wagner K, Petek E (2004) Cloning, genomic structure, and expression profiles of TULIP1 (GARNL1), a brain-expressed candidate gene for 14q13linked neurological phenotypes, and its murine homologue. Genomics $84: 577-586$.

Scotton P, Bleckmann D, Stebler M, Sciandra F, Brancaccio A, Meier T, Stetefeld J, Ruegg MA (2006) Activation of muscle-specific receptor tyrosine kinase and binding to dystroglycan are regulated by alternative mRNA splicing of agrin. J Biol Chem 281:36835-36845.

Serpinskaya AS, Feng G, Sanes JR, Craig AM (1999) Synapse formation by hippocampal neurons from agrin-deficient mice. Dev Biol 205:65-78.

Shi Y, Ethell IM (2006) Integrins control dendritic spine plasticity in hippocampal neurons through NMDA receptor and $\mathrm{Ca}^{2+} /$ calmodulindependent protein kinase II-mediated actin reorganization. J Neurosci 26:1813-1822.

Soriano MA, Tessier M, Certa U, Gill R (2000) Parallel gene expression monitoring using oligonucleotide probe arrays of multiple transcripts with an animal model of focal ischemia. J Cereb Blood Flow Metab 20:1045-1055.

Stone DM, Nikolics K (1995) Tissue- and age-specific expression patterns of alternatively spliced agrin mRNA transcripts in embryonic rat suggest novel developmental roles. J Neurosci 15:6767-6778.

Sugita S, Saito F, Tang J, Satz J, Campbell K, Sudhof TC (2001) A stoichiometric complex of neurexins and dystroglycan in brain. J Cell Biol 154:435-445.

Talts JF, Andac Z, Gohring W, Brancaccio A, Timpl R (1999) Binding of the $\mathrm{G}$ domains of laminin alpha1 and alpha2 chains and perlecan to heparin, sulfatides, alpha-dystroglycan and several extracellular matrix proteins. EMBO J 18:863-870.

Thaler J, Harrison K, Sharma K, Lettieri K, Kehrl J, Pfaff SL (1999) Active 
suppression of interneuron programs within developing motor neurons revealed by analysis of homeodomain factor HB9. Neuron 23:675-687.

Thomas GM, Huganir RL (2004) MAPK cascade signalling and synaptic plasticity. Nat Rev Neurosci 5:173-183.

Tian M, Hagg T, Denisova N, Knusel B, Engvall E, Jucker M (1997) Laminin-alpha2 chain-like antigens in CNS dendritic spines. Brain Res 764:28-38.

Tsen G, Halfter W, Kroger S, Cole GJ (1995) Agrin is a heparan sulfate proteoglycan. J Biol Chem 270:3392-3399.

Valenzuela DM, Stitt TN, DiStefano PS, Rojas E, Mattsson K, Compton DL, Nunez L, Park JS, Stark JL, Gies DR, Thomas S, Le BMM, Fernald AA, Copeland NG, Jenkins NA, Burden SJ, Glass DJ, Yancopoulos GD (1995) Receptor tyrosine kinase specific for the skeletal muscle lineage: expression in embryonic muscle, at the neuromuscular junction, and after injury. Neuron 15:573-584.
Verhage M, Maia AS, Plomp JJ, Brussaard AB, Heeroma JH, Vermeer H, Toonen RF, Hammer RE, van den Berg TK, Missler M, Geuze HJ, Sudhof TC (2000) Synaptic assembly of the brain in the absence of neurotransmitter secretion. Science 287:864-869.

Watanabe M, Fukaya M, Sakimura K, Manabe T, Mishina M, Inoue Y (1998) Selective scarcity of NMDA receptor channel subunits in the stratum lucidum (mossy fibre-recipient layer) of the mouse hippocampal CA3 subfield. Eur J Neurosci 10:478-487.

Yang X, Arber S, William C, Li L, Tanabe Y, Jessell TM, Birchmeier C, Burden SJ (2001) Patterning of muscle acetylcholine receptor gene expression in the absence of motor innervation. Neuron 30:399-410.

Yoda A, Oishi I, Minami Y (2003) Expression and function of the Rorfamily receptor tyrosine kinases during development: lessons from genetic analyses of nematodes, mice, and humans. J Recept Signal Transduct Res 23:1-15. 